\title{
The Anatomy of the Six Epiphytic Species of the New Zealand Orchidaceae.
}

\author{
BY
}

\section{K. M. CURTIS, M.A. \\ With Plates VII-XII.}

THE following is an enumeration of the six epiphytic species of 1 New Zealand Orchids dealt with in the present paper, with notes on their geographical distribution. ${ }^{1}$

Earina, Lindl. Besides the two species found in New Zealand, which are endemic, there are four others from the Pacific Islands.

$E$. mucronata: not uncommon in lowland districts throughout North and South Islands, Stewart Island, and the Chatham Islands ; ranges from sea-level to $2,000 \mathrm{ft}$.

E. suaveolens: North and South Islands and Stewart Island; sealevel to $2,000 \mathrm{ft}$.

Dendrobium, Swartz. A large genus of about 300 species, most abundant in the Malay Archipelago, but extending as far north as Japan, and southward through Australia and Polynesia to New Zealand. The single species found in New Zealand is endemic, but is closely allied to the Polynesian D. biflorum, Swartz.

D. Cunninghamii : North and South Islands, and Stewart Island; sea-level to $2,000 \mathrm{ft}$.

Bulbophyllum, Thouars. A genus of nearly 100 species with its chief centre of distribution in tropical Asia, but also found in tropical Africa, Australia, New Zealand, and sparingly in South America.

B. pygmaeum : North and South Islands, in the South chiefly on the western side; sea-level to $I, 500 \mathrm{ft}$.

$B$. tuberculatum: rather restricted in range. Has been seen in the Auckland, Hawke's Bay, and Wellington districts in the North Island, and in the Nelson district in the South Island,

Sarcochilus, R. Br, A genus of about thirty species, most of them from India, the Malay Archipelago, and Australia ; a few from the Pacific Islands, and one from New Zealand.

1 Distribution and morphological descriptions, excerpts from Cheeseman (3).

[Annals of Botany, Vol. XXXI. No. CXXI. January, 1917.] 
S. adversus: occurs in the lowland districts of North and South Islands, Stewart Island, and the Chatham Islands, but is not common.

Earina mucronata, Lindl. Bot. Reg. sub t. I699.

Stem creeping. Branches numerous, I $-3 \mathrm{ft}$. long, slender, simple, pendulous or rarely erect, smooth, compressed and two-edged, spotted. Roots long, thick or slender, with smaller branch roots at intervals. Leaves $3^{-6}$ in. long, $\frac{1}{6}-\frac{1}{5}$ in. broad, narrow linear, acuminate, flat, smooth, thin but coriaceous, very finely striate. Panicle terminal, many-flowered. Flowers rather distant, $\frac{1}{4}$ in. diameter. Sepals and petals pale yellow, lip darker with brownish orange spot at the base.

Roots and rootlets are a dull white colour except near the tips where the velamen has not yet become filled with air and the green of the cortex is still visible. The central cylinder contains from eleven to thirteen alternating groups of xylem and phloem, and is surrounded by a thinwalled cortex occupying the greatest portion of the root (Pl. VII, Fig. I). Outside the cortex lie the exodermis and a velamen of several rows. Root-hairs are frequently present, especially in flattened specimens where the substratum adjoins. When the velamen consists of four rows, the three outer are somewhat similar to one another. In transverse section their cells are practically isometric; the thickening strands are reticulately arranged, but have a general tangential direction. In longitudinal section the cells are elongated and the strands run more or less parallel to the long axis of the root. The innermost layer of the velamen consists of large cells tangentially elongated in transverse section; the strands on all their walls are radial. Cutinization of walls and strands occurs throughout the velamen and is especially heavy in the cells near the exodermis. The latter consists of a single row of cutinized elements whose continuity is broken by the occurrence, at intervals of usually four cells, of smaller passage cells with cellulose walls. The thickened cells are somewhat compressed tangentially, but are much elongated in the longitudinal direction. Thickening and cutinization occur on their radial and external tangential walls only. The former are finely striated. The two walls forming the angle on the cortical side are of cellulose. In longitudinal section passage cells alternate with cutinized cells. The denser protoplasmic contents and large nuclei of the former present a contrast to the thin protoplasmic lining and small nuclei of the latter.

The cells of the cortex vary in depth from eight in the smaller branches to twenty or more in the principal roots. The unusual thickness of some roots is due chiefly to a greater depth of cortex, but a few additional rows in the velamen may occur at the same time. Two small cells always bound the inner walls of the passage cells. The largest cells lie in the central portion of the cortex, while they diminish in size towards exodermis and 
endodermis. Near the outer and inner limits of the cortex the cells are longitudinally elongated, and the walls heavily pitted with round, oval or slit-like pits; in the row adjoining the endodermis the walls are usually reticulately marked. A few of the large central cells are covered with fine spiral thickening strands. Small thin-walled cells containing raphides occur in the two outermost layers of the cortex. The endodermal cells, which are large and elongated, have thick, striated, cutinized walls with numerous pits. When the lumina are small the nuclei are filiform. The passage cells, which lie opposite the protoxylem groups, are a little smaller than the other members of the endodermis and contain denser protoplasm. In a large root they may be slightly cutinized. The cells of the pericycle are elongated in longitudinal section, and the walls, except of those adjoining passage cells, are thickened and cutinized. There are usually twelve, thirteen, or eleven groups of xylem and phloem present. The numerous small elements of the former consist of diversely pitted tracheides and of spiral vessels ; the few larger elements are usually spiral vessels. The sieve-tubes are small, but at least one in each group considerably exceeds the others. Separating xylem and phloem are a few sclerenchymatous fibres. Elongated, cutinized cells lie within the vascular region, while those at the extreme centre of the cylinder have walls of cellulose. Chlorophyll occurs in the cortex chiefly in the three rows adjoining the exodermis, and in two or three adjoining the endodermis. The larger cells contain little, if any. In the outer region the two small cells which lie next to the passage cells of the exodermis contain distinctly the most. In addition a few granules may be present in the cellulose cells at the centre of the cylinder. Fungal hyphae branch in numbers through the cells of the velamen. Eventually they pass into a passage cell, where they take several turns round the nucleus, and then proceed into the cortex. Here they seldom penetrate deeper than the fifth cell, where they are reduced to globular masses of disorganizing hyphae connected together through the cell-walls by mere fibrils. If the cortical cell is large it may contain a smaller secondary, in addition to the nuclear, mass of fungus. The nuclei of the cells are always larger when the fungus is present.

The stem has a narrow cortex surrounding an irregular ring of sclerenchymatous fibres, within which lie the numerous large vascular bundles. The cuticle is heavy-at times wider than the epidermal cells. These are cutinized and somewhat elongated in longitudinal section. Their inner walls are thicker than their outer, but the former are the more heavily pitted. In the elongated, pointed elements comprising the cortex the intensity of cutinization diminishes from without inwards, while the quantity of starch contained increases. The cortex gives place abruptly to the sclerenchymatous fibres of the strengthening cylinder. These pass gradually into the oval cells comprising the ground tissue. The latter are filled with dense masses of starch tetrads. The vascular strands which occur 
in the ring of sclerenchyma are smaller than those lying in the conjunctive tissue. The phloem of all the strands is protected by fibres whose walls bear several striations. Fibrous elements may be absent from the periphery of the xylem. If present, they usually have larger lumina and contain starch. Small and large spiral vessels are to be seen in the xylem, and tracheides, especially those with equidistant pits, are of frequent occurrence.

The branch is of one order only, and bears about six leaves at an inch or an inch and a half apart. The leaf is continued below in an unbroken sheath to its node where the next lower blade bends out from its sheath. The sheaths are dull in colour, with regular lines or irregular groups of darker brown, due to the complete or partial discoloration of the many sclerenchymatous strands running parallel to the surface (Pl. VIII, Fig. I8). Only the largest of these strands contain vascular bundles, and many of the fibres are devoid of contents. The cells of the general tissue of the sheath are strewn with so many large pits of irregular shape that a reticulate appearance is lent to the walls. This is most noticeable in the spindle-like cells which adjoin or cross the large canals lying between the strands of sclerenchyma. Each of these cells contains a spherical crystal aggregate. Only two or three elements are present in the phloem and xylem of the vascular bundles.

The branch is oval in transverse section. Its cortex is narrow, but within it is a wide band of sclerenchyma in which are embedded most of the vascular bundles. Only a few strands occur in the ground tissue. A heavy cuticle covers the free surface of the small epidermal cells. The outer cells of the cortex are cutinized, but the inner are of cellulose. All are pitted and elongated in longitudinal section and most contain starch. The vascular bundles in the sclerenchymatous ring are seldom large. Usually about six elements are present in xylem and phloem. Those of the central portion of the branch are well developed and may have complete sheaths of sclerenchyma. More often this is absent on the side of the xylem, but two or three cells deep on that of the phloem. The cells of the ground tissue, which are oval in transverse and elongated in longitudinal section, are filled with dense masses of starch.

The leaf is strengthened by the presence of much sclerenchyma (Pl. VIII, Fig. 24). All the bundles are surrounded by large fibrous sheaths ; numerous sclerenchymatous strands run immediately within the two epidermes, especially the upper ; and a broad strand is present at the edge of the leaf. The isolated strands near the epidermes consist of from one to six fibres. Their contents disappear early, and few pits or striations occur in their walls. There are usually nineteen vascular bundles in the leaf. The elements of their sheaths vary in size; near the xylem they are large and often without striations; near the phloem they are smaller, striated, and pitted, and retain their protoplasmic contents. Most of the smaller 
tracheides have their pits arranged in regular order a little distance apart; in the larger the pits are more elongated, but closer together. Cuticle occurs on both surfaces, but is thicker on the upper. The cells adjoining the upper epidermis are somewhat elongated in transverse section, and in tangential section they resemble palisade structure to a certain extent. Below this row they contain numerous chlorophyll granules. In the assimilatory tissue of the lower portion of the leaf the cells are connected together by short tubular extensions, across each of which is a pitted diaphragm. Large intercellular spaces occur in this region. Isolated elements, elongated in tangential section and containing raphides, are to be found between the vascular bundles lying towards the edge of the leaf. Stomata occur on the lower surface. Their walls are extremely thick, and the outer are covered by the cuticle. Above the midrib the cells are large and thin-walled; their protoplasm is vacuolated, and they contain few chlorophyll granules.

Earina suaveolens, Lindl. Bot. Reg. (I843) Misc. 6I.

Stems stout, erect or pendulous, slightly compressed, 6-I 8 in. high. Branches numerous, close-set. Leaves $2-4$ in. long, $\frac{1}{3}-\frac{1}{2}$ in. broad, narrow linear, acute, rigid, coriaceous, striate, midrib evident. Panicle terminal, 2-4 in. long, many-flowered. Flowers sessile, much closer together than in $E$. mucronata, $\frac{1}{4}-\frac{1}{3}$ in. in diameter, waxy-white with a yellow centre; very fragrant.

The root does not usually branch. Its velamen consists of from three to five rows of cells, of which only the inner have cutinized walls (Pl. VIII, Fig. 28). The thickening strands on all the walls are more or less radial. The innermost cells are elongated in both tangential and longitudinal directions; fewer strands are present on their walls than on those of the outer rows. In the exodermis only the outer and the radial walls are cutinized. Three or four thickened cells occur between any two passage cells. Adjoining the latter on the inner side are the usual two small cortical cells containing numerous chlorophyll granules. Reticulately pitted cells are present in the outer and in the innermost rows of cortex, especially in the latter. The larger cells in the middle region have spiral bands or pits of various sizes in their walls. Chlorophyll occurs throughout, but it is denser near the inner and outer limits. Cells containing raphides lie near the exodermis. The walls of the thickened cells of the endodermis are cutinized and striated, while those of the passage and of the one or two adjoining pericycle cells are of cellulose. Twelve groups of xylem and phloem are usually present. As in E. mucronata, the former consist of small tracheides and spiral vessels, and the latter of sieve-tubes and companion cells. Sclerenchymatous fibres lie between the groups, but near the centre of the cylinder they give place to large cellulose-walled elements containing a little chlorophyll. 
A depth of about twenty cells in the cortex gives a parenchymatous appearance to the stem. There is no complete sclerenchymatous ring, but the outer vascular bundles have extended sheaths which may almost, if not actually, touch. The minute epidermis is bounded by a thick cuticle. The size of the cortical cells is greatest in the central region and diminishes towards either edge. Small intercellular spaces occur between the largest cells, which are oval in shape, and again between the small round cells of the innermost rows. Little marking is visible in any of the walls. What does occur is due chiefly to the occurrence of small pits. Raphides are present in the outer cortex. The phloem sheath of the central vascular strands is frequently four cells deep, and the walls of those of its fibres which adjoin the ground tissue are heavily pitted. The usual elements occur in the somewhat large strands of xylem and phloem. As a rule the vascular bundles are separated from one another by two rows of the large oval cells of the ground tissue. These have thick, heavily pitted, cellulose walls and contain great quantities of starch.

The leaf sheath resembles that of $E$. mucronata, but is firmer in every way (P1. IX, Fig. 39). Nearly all the large sclerenchyma strands enclose vascular bundles. The cuticle is thick, especially on the outer epidermis. Pits are wide and numerous in the general tissue, particularly in the reticulately marked cells near the canals. The vascular sheaths contain many small fibres, but at the junction of xylem and phloem their elements are larger and have thinner walls.

In the branch a great number of vascular bundles occur throughout the cutinized ground tissue. A heavy cuticle is present. The cells of the fourto five-rowed cortex are elongated in longitudinal section and may contain a little chlorophyll, while the ground tissue is filled with tetrahedrally arranged starch granules. The vascular elements resemble those of the stem. At the centre of the branch the sheaths do not extend round the xylem.

In the leaf the two halves are practically in the same plane, but the edge may be slightly recurved. There are usually twenty-three vascular bundles, and of these five are large. Small sclerenchymatous strands run parallel to the leaf surface immediately within the two epidermes, but they are not as large, nor proportionately as numerous, as in the leaf of $E$. mucronata. The group of fibres at the edge of the leaf lies close to the lower epidermis. There is a distinct furrow above the midrib and a slight one above each of the other large vascular bundles. The cells of three or four rows near the upper epidermis are arranged in palisade formation. The walls are thin and pitted, the protoplasmic contents vacuolated, and fewer chlorophyll granules are present here than elsewhere. This resemblance to water-storing tissue is more noticeable in the cells lying over the midrib. The elements of the epidermis are regular in shape. Their walls 
are somewhat thickened and the outer are slightly mucilaginous. Stomata are confined to the lower surface of the leaf, and are not numerous. Spiral vessels occur occasionally in the xylem, but tracheides are the more usual elements.

\section{Dendrobium Cunninghamii, Lindl. Bot. Reg. sub t. $175^{6}$.}

Stems usually much branched, slender, rigid, wiry, terete and polished, I-4 ft. long; usually pendulous, but small specimens growing on rocks or in exposed places are often erect. Leaves numerous, distichous, alternate, $\frac{3}{4}-2$ in. long, $\frac{1}{6}-\frac{1}{5}$ in. broad, linear-lanceolate, acute, rigid, and coriaceous, striate and more or less conspicuously 3 -nerved ; sheaths truncate, grooved, and transversely corrugated. Flowers $\frac{3}{4}$ in. in diameter, white and pink.

The root as a whole, and all the cells individually, are large (Pl. IX, Fig. 47). Of the usual four rows in the velamen, the three outer are more or less alike, while the inner is elongated radially and has its outer walls inclined to one another. Root-hairs are often present. In transverse section the elements of the velamen immediately over a passage cell look like two or three triangles of different altitudes, standing on a common base, one within the other, and having their apices connected by a zigzag line to the centre of the base. In longitudinal section the walls of these cells resemble portions of concentric circles. Except in these walls the fine thickening strands of the velamen are radial. The exodermal walls may have several striations. They are all cutinized, even the inner tangential. The elements of the cortex are thin-walled and regular in shape. In the central region and near the endodermis they are usually round. Chlorophyll is present, but not in great quantities. Small round pits occur frequently, but spiral bands are seldom to be seen. As in the preceding genus the cortical cells adjoining the endodermis are reticulately pitted. The endodermis is well marked. Its cells are large, radially elongated, and heavily cutinized. The passage cells, which are small, occur about every sixth cell. They are distinctive in being elongated in longitudinal section. The walls of pericycle and conjunctive tissue are cutinized, but the lumina are large. Ten or more strong alternating vascular groups are present. A number of small, and one or two much larger, elements occur in the xylem. The tracheides usually have reticulate or regular equidistant pits. A few fibres may be present in the phloem.

Stem and branch resemble each other closely. A thick cuticle surrounds a peripheral sheath of sclerenchymatous fibres which extends to a depth of about one-fifth of the radius. The cortex is narrow, and consists of thick-walled cells containing a little chlorophyll. Here and there the sheaths of the outer vascular strands join one another. Chlorophyll may also occur in the somewhat thin-walled elements of the ground tissue. 
The leaf has a central and two smaller lateral depressions. Near the edge the lower surface slopes gradually towards the upper. No isolated strands of sclerenchyma are present. The rigidity of the leaf is due to the presence of strikingly large vascular sheaths whose outline in transverse section resembles roughly that of the figure 8 . The largest strand lies in the centre of each leaf-half. The fibres are small and have many striations except where phloem and xylem meet. Surrounding each sheath is a single ring of small hexagonal thin-walled cells containing numerous chlorophyll granules. Between the vascular strands the cells of the assimilatory tissue are much elongated in transverse section, while above and below this region they are more nearly oval. Numerous intercellular spaces are present in the lower half of the leaf. Club-shaped cells, attached to small basal cells, occur sparingly in the upper epidermis and infrequently in the lower. The epidermal cells adjoining the basal cell are smaller than usual, and their walls are distinguished by the presence of large elongated pits. The inner and outer walls of the two epidermes undergo pectic mucilaginization. The cells of the upper are unusually large. Minute round pits stud the walls, especially those separating two epidermal elements. Above the midrib the cells, which are elongated in the direction perpendicular to the leaf surface, resemble the epidermis in the mucilaginous nature of their walls, in their vacuolated protoplasm, and in the size and shape of their pits.

\section{Bulbophyllum pygmaeum, Lindl. Gen. et Sp. Orch. $5^{8}$.}

Minute, forming densely matted carpets on the trunks of trees or on rocks. Pseudo-bulbs $\frac{1}{2}-\frac{1}{6}$ in. in diameter, globose, glabrous. Leaves solitary on the pseudo-bulbs, springing from a minute circular sheath $\frac{1}{4}-\frac{1}{3}$ in. long, linear-oblong, obtuse, very thick and coriaceous, grooved down the middle and minutely echinulate above, longitudinally nerved beneath. Peduncles solitary from the base of the pseudo-bulbs, $\frac{1}{3}-\frac{1}{6}$ in. long, I-flowered. Flowers very minute, whitish.

The root is very small ( $\mathrm{Pl}$. X, Fig. 57). The velamen consists of a single row of regular, comparatively large cells lacking thickening strands. The inner tangential walls are thick and cutinized; the radial are of cellulose and diminish in thickness towards the surface of the root, where the outer tangential walls are very thin. The thickened exodermal cells have cutinized striated walls and the passage cells are often of equal size. The cells of the cortex have no spiral thickening strands. They are four to six deep, are small at the inner and outer limits, but in the centre are large and oval with distinct intercellular spaces. The longitudinal walls of the row adjoining the endodermis are reticulately pitted. Raphides are present in certain cells of the second layer from the exodermis. Chlorophyll occurs throughout the cortex, but is more abundant in the small cells adjoining the exodermal 
passage cells. In transverse section the endodermis has an open appearance due to the presence of two passage cells together and to the large lumina of the cutinized cells. Five groups of xylem and phloem are usual. Their elements are small and seldom more than six in number. The centre of the cylinder is filled with fibres.

In transverse section the stem is sinuous in outline (Pl. X, Fig. $5^{8}$ ). The epidermal cells, which are slightly elongated in the tangential direction, have mucilaginous walls. The outer portion of the cortex consists of large semi-collapsed cells with scanty contents. The cells of the inner portion have firm walls with numerous pits which in longitudinal section are frequently arranged in a reticulate manner. Chlorophyll is present in this part of the cortex and in the ground tissue of the centre of the stem. The vascular bundles may have complete sheaths of sclerenchyma, especially if they lie towards the periphery. Their elements are numerous but not large. The xylem consists only of various kinds of tracheides.

The leaf is very thick and has rounded edges. Both epidermes are wide, the upper exceptionally so. Below it are several rows of cells whose shape bears a resemblance to palisade tissue. The general assimilatory tissue consists of somewhat large round cells connected together by tubular processes, in the diaphragms of which two to five circular pits are to be seen. Of the fifteen vascular bundles the midrib and four others exceed the remainder in size. The sheaths are strong, especially on the phloem side, where their elements are unusually large. Xylem and phloem groups are somewhat small. Spiral and pitted tracheides alone are to be found in the former. Single cells containing raphides occur midway between the vascular bundles lying towards the leaf edge. Occasionally a clubshaped sunken cell with elongated pits in its walls occurs in the upper epidermis. Beneath it the 'palisade' cells fit more closely than usual. On the upper surface each cell of the epidermis is produced into a stout papilla over which the thick cuticle is continued. The appearance of the upper half of the leaf is suggestive of water storage. Large vacuoles are present in the protoplasm of the epidermis; pits occur in the walls, especially in those separating two adjacent epidermal cells. In the 'palisade' region vacuoles are numerous, though smaller; pits are of frequent occurrence; the number of chlorophyll granules is small in comparison with that in the lower portion of the leaf. Mucilaginization of the walls occurs throughout; it is most marked in the epidermis, weaker in the 'palisade' region, and least in the general cells of the lower part of the leaf.

In the pseudo-bulb the vascular strands follow one of two courses. Those originating in the upper portion of the stem usually run to the apex with but slight deviation; those, however, which come from the side of the stem bend outward and follow the contour of the pseudo-bulb at a little distance from its edge. Just below the apical cavity they unite to form the 
five bundles present in the lowest portion of the leaf. The vascular strands are weak, but small tracheide-like cells serve as an extension of the system. The cuticle is continued a short distance over the rim at the apex of the pseudo-bulb into the cavity. The epidermal cells have thick heavily pitted walls. Raphides occur near the surface. The general mass of tissue consists of somewhat large thin-walled cells containing numerous chlorophyll granules, and scattered profusely among these, but in no definite order, still larger water-storing elements. These lie with their greatest axis in the horizontal plane. Their walls are thin, but are densely covered with fine spiral bands. Pectic mucilaginization takes place in the walls of many of the assimilatory cells. At some of the angles where several join the walls separate along the swollen middle lamella and form intercellular spaces with a mucilaginous lining. In the central portion of the pseudo-bulb storage cells are of less frequent occurrence, while the assimilatory cells, though smaller in this region, contain more chlorophyll. A continuation of the lower end of the leaf blade is distinguishable in the tissue of the apical region of the pseudo-bulb. The leaf in this stage is folded about the midrib with the two halves of the upper surface in contact. Its cutinized upper epidermis may be detected a short distance beneath the cavity. Cutinization of the lower epidermis and separation from the tissue of the pseudo-bulb continue symmetrically from the contiguous leaf-edges, round the two halves of the lower surface, to the point opposite the midrib. The five vascular bundles present at this stage have strong sclerenchymatous sheaths and a rather large development of phloem.

Bulbophyllum tuberculatum, Col. in Trans. N. Z. Inst. xvi (I884), 336 and xxii (1890), 488.

Forms matted patches on the trunks or branches of trees. Pseudo-bulbs $\frac{1}{4}-\frac{1}{3}$ in. long. Leaves solitary on the pseudo-bulbs, $\frac{1}{2}-\mathrm{I}$ in. long, linearoblong, acute at both ends, thick and fleshy, slightly concave above, midrib prominent beneath. Peduncles almost filiform, $\frac{1}{2}-\frac{3}{4}$ in. long, 2-4 flowered. Flowers $\frac{1}{6}$ in. long, white with a bright reddish-orange lip.

The root is larger than that of $B$. pygmaeum, but its general features are similar (Pl. XI, Fig. 72). The cells of the single-rowed velamen are very large. Their radial walls do not perceptibly diminish in thickness towards the outer surface as do those of the preceding species. No thickening strands occur on any of the walls. In transverse section the exodermal cells are pointed in the radial direction. The cells of the outermost row of the cortex, and sometimes of the second row also, contain abundant chlorophyll granules. Several rows of large cells may be present in its central region. Intercellular spaces are of frequent occurrence, especially near the endodermis. The uniformity of the latter is somewhat broken by irregularity in the size of the cutinized cells and by the presence of two passage cells 
together. There are often six groups of xylem and phloem, the former being proportionately the better developed and consisting almost wholly of spiral tracheides. In the centre of the cylinder the cells have thin, slightly cutinized walls.

In the stem the epidermis and cortex are thin-walled. The latter, which is not usually more than eight cells deep, consists of large elements containing raphides, separated by small cells with protoplasmic contents. Spirally marked water-storage cells occur infrequently. The vascular bundles are numerous and the fibres of their sheaths large. Of the latter there are usually two or more rows near the phloem and one near the xylem. Spiral tracheides are of general occurrence, but reticulate and regularly pitted tracheides are also to be seen.

The pseudo-bulb is taller, more pointed at the apex, and contains more vascular bundles than that of $B$. pygmaeum. The regular, slightly elongated cells of the epidermis are protected by a heavy cuticle. The general tissue consists of large spirally marked water-storage cells and small assimilatory cells with numerous chlorophyll granules. Near the periphery of the pseudo-bulb one green cell lies at the angle of juncture of several storage cells, but near the vascular bundles and in the central region several green cells may occur together, and the large elements be segregated in groups of two or three. In longitudinal section assimilatory cells usually surround each storage cell. In the apical portion of the pseudo-bulb the small cells near the surface contain instead of chlorophyll a purple pigment in solution in the cell sap. The vascular strands are weak. A few slightly thickened elements occasionally adjoin the phloem.

The leaf is broader, but proportionately thinner than that of $B . p y g$ maeum. Five large and ten smaller bundles traverse its length. The cells of the upper epidermis are extremely large. No papillae are present, but small sunken cells occur at somewhat rare intervals on the upper surface. Below the epidermis are two or three rows of cells with slight contents. Between the vascular strands the assimilatory cells are much elongated in the plane parallel to the leaf surface. Below these again lie more or less round cells connected together by tubular extensions. Large air chambers occur between the small stomata and the assimilatory tissue, and cells containing raphides are present between the outer vascular bundles. One epidermal cell at the extreme edge of the leaf is extended into a short projection, with the result that the leaf margin is sharp.

Sarcochilus adversus, Hook. f. Fl. Nov. Zel. i. 24I.

Roots numerous, long, wiry, terete. Stems short, I-3 in. long, concealed by the imbricated sheathing bases of the leaves. Leaves few, distichous, spreading, I-2 $\frac{1}{2}$ in. long, $\frac{1}{3}-\frac{3}{4}$ in. broad, linear-oblong to ellipticoblong, obtuse or sub-acute, jointed above the sheathing base, thick and 
coriaceous, dark green, often spotted with purple. Peduncles $I-4$ from the axils of the lower leaves, slender, $I-2 \frac{1}{2}$ in. long, $5^{-1} 5$ flowered. Flowers $\frac{1}{8}-\frac{1}{6}$ in. in diameter, green spotted with purple.

The velamen consists of two or three rows of cells, the outer of which are large, thin-walled and covered with fine parallel radial strands (Pl. XII, Fig. 89). The cells within this row are irregular in size, devoid of thickening strands, and cutinized in the walls which adjoin the exodermis. The protective cells of the latter layer are much larger than the passage cells. Spirally thickened water-storage cells occur in numbers from exodermis to endodermis, and raphides are not uncommon throughout the same region. The cortex as a whole contains an unusual amount of chlorophyll. The walls of the endodermis are so heavily thickened that only narrow radially elongated lumina remain. Near the passage cells, which occur singly, the walls of from one to three of the pericycle cells are of cellulose. From ten to thirteen vascular strands are present. In the conjunctive tissue the degree of cutinization diminishes towards the centre of the cylinder, where a little chlorophyll may occur.

A thick cuticle covers the stem. The cortex is nearly one-third of the radius in depth, and is composed of small assimilatory cells and numbers of irregularly scattered large raphides cells. The vascular bundles are well developed, and the sheaths, especially of those near the edge of the vascular region, contain many sclerenchymatous elements on the side of the phloem. Chlorophyll is present in the pitted cells comprising the ground tissue.

The strength of the thick leaf is dependent upon its succulent nature. No sclerenchyma is present except that in connexion with the vascular strands. The sheaths are seldom complete, and only those of their elements which adjoin phloem have heavily thickened walls. Large raphides cells abound. Chlorophyll granules occur from upper to lower epidermis, although in fewer numbers in the upper cells. Xylem and phloem contain numerous elements of regular size.

\section{SUMMARY.}

I. The velamen consists of one row of cells in Bulbophyllum pygmaeum and B. tuberculatum and of two or three rows in Sarcochilus adversus; the number in the two species of Earina and in Dendrobium Cunninghamii is more variable, ranging from three to five, or more.

2. The greatest amount of chlorophyll, in proportion to the size of the root, occurs in Sarcochilus adversus, and next in the two species of Bulbophyllum. Less is present in the Earinas and in Dendrobium Cunninghamii.

3. A great number of spirally thickened water-storage cells are present in the cortex of the root of Sarcochilus adversus; they are also to be seen, though less frequently, in the two species of Earina.

4. Fungal hyphae are present in the roots of all; they penetrate to the 
endodermis in Bulbophyllum pygmaeum and B. tuberculatum; almost every cell in the outer portion of the cortex of Dendrobium Cunninghamii contains one or more large disorganizing masses.

5. a. An internal cylinder of sclerenchyma and starch in cortex and ground tissue occur in stem and branch of Earina mucronata; there is no complete sheath of sclerenchyma in E. suaveolens.

$b$. A peripheral cylinder of sclerenchyma and chlorophyll in cortex and ground tissue are present in Dendrobium Cunninghamii.

c. In Bulbophyllum pygmaeum the inner half of the cortex and the ground tissue contain chlorophyll.

d. In $B$. tuberculatum and Sarcochilus adversus raphides cells occur throughout the assimilatory tissue.

6. a. Isolated sclerenchyma strands are present in the leaves of the two species of Earina; a 'palisade' arrangement of thin-walled cells containing little chlorophyll occurs beneath the upper epidermis of $E$. suaveolens.

$b$. Very large vascular sheaths but no isolated strands are present in Dendrobium Cunninghamii; its wide epidermis is mucilaginous.

c. The leaves of the species of Bulbophyllum are succulent ; mucilaginization takes place in the walls, especially in those of the epidermis ; pseudo-bulbs are present.

$d$. The leaf of Sarcochilus adversus is very succulent; great numbers of raphides cells occur throughout.

I am indebted to Professor J. C. Johnson, University College, Auckland, N.Z., for criticism and guidance, and, later, to Professor J. B. Farmer, Imperial College of Science and Technology, South Kensington, for advice on several points.

Imperial College of Science and Technology.

\section{LITERATURE.}

1. Burgeff, H.: Die Wurzelpilze der Orchideen. Jena, 1909.

2. Chatin, Ad.: Anatomie des plantes de l'ordre des Orchidées. ${ }^{\text {er }}$ Mém.: Anat. des racines. Mém. de la Soc. des sc. nat. de Cherbourg, t. iv, I $85^{6}$. $2^{\mathrm{e}}$ Mém.: Anat. du rhizone, de la tige, et des feuilles. Mém. de la Soc. des sc. nat. de Cherbourg, t. v, 1857 .

3. Chemseman, T. F.: Manual of the New Zealand Flora.

4. Constantin, J.: Recherches sur l'influence qu'exerce le milieu sur la structure des racines. Ann. des sc. nat., Bot., I 885 , sér. vii, t. i, p. I 40 .

5. Goebel, K. : Pflanzenbiologische Schilderungen, Teil i, p. 188.

6. JANCZEWSKI, ÉD. DE: Organisation dorsiventrale dans les racines des Orchidées. Ann. des sc. nat., Bot., I 885 , sér. vii, t. ii, p. 55 .

7. Leitgeb, H. : Die Luftwurzeln der Orchideen. Denkschriften der K. Akad. der Wissenschaften, vol. xxiv, 1865 .

8. Schimper, A. F. W.: (a) Ueber Bau und Lebensweise der Epiphyten Westindiens. Bot. Centralblatt, 1884. (b) Die epiphytische Vegetation Amerikas. Jena, I888. 


\title{
EXPLANATION OF THE FIGURES IN PLATES VII-XII.
}

\author{
Illustrating Miss Curtis's paper on the Anatomy of the Six Epiphytic Species of the \\ New Zealand Orchidaceae.
}

T.S. = transverse section; L.S. = longitudinal section.

PLATE VII.

\section{Earina mucronata.}

Fig. I. Root, T.S.: cel., centre of cylinder where the cell-walls are of cellulose; $c y$., central cylinder; ph., phloem; $x_{\text {. }}$, xylem; end., endodermis ; c., cortex ; exo., exodermis ; v., velamen; $r t . h .$, root-hair. Diagrammatic.

Fig. 2. Root, outer portion, L. S. : v., velamen ; exo., exodermis ; p.c., passage cell ; t.c., reticulately pitted cross-wall; chl., chlorophyll. $\times 360$.

Fig. 3. Raphides cell, L. S., from outer portion of cortex : $r_{\text {., }}$ raphides; $p_{\text {. }}$ pit; $n_{\text {., nucleus. }}$ $\times 112$.

Fig. 4. Cortical cells, root, L. S.: chl., chlorophyll ; p., pit ; pr., protoplasm; n., nucleus. $\times 112$. $\times$ II 2 .

Fig. 5. T.S. two cutinized elements from outer region of cortex of root: lettering as before.

Fig. 6. L. S. cutinized element; cf. Fig. 5. $\times$ II 2.

Fig. 7. Root, outer portion, T.S. : v., velamen; s., thickening strand ; b.s., section of thickening strand; p.c., passage cell ; $f$., fungus ; f.c., coil of fungus; $r_{\text {. }}$, raphides ; exo., exodermis ; $\mathrm{k}$, where cutinization of the wall ceases. $\times 620$.

Fig. 8. L. S. passage cell of root; i.v., cell of innermost row of velamen; $c$, accumulation of fungal hyphae outside passage cell; c.n., coils of fungus with cell nucleus; p.c., passage cell; $h$., hypha passing to cortex. $\times 620$.

Fig. 9. Stem, T. S., outer portion : cut., cuticle ; epi., epidermis ; cu.c., cutinized cells; cell c., cells with walls of cellulose; st., starch; r.scl., portion of sclerenchyma cylinder; ph., phloem; $x$., xylem; $x . s c l$, xylem sclerenchyma. $\times 360$.

Fig. IO. Root, portion of central cylinder, T.S. : p.c., passage cell ; p.x., protoxylem; end., endodermis ; peric., pericycle; c.c., companion cell; s.t., sieve-tube; $x$., xylem; cut.w., cutinized wall ; cell.w., cellulose wall of elements of centre of cylinder. $\times 360$.

Figs. I I, I2. Small pitted tracheides of root : $p$., pit ; $t$., unpitted portion of wall. $\times 620$.

Fig. I3. Tracheide of root. $\times 620$.

Fig. I4. Reticulate tracheide of root. $\times 620$.

Fig. 15. L. S. endodermis of branch root : i.c., innermost row of cortex; end., endodermis; $n$. end., nucleus of endodermal cell ; p., pit; peric., pericycle. $\times 360$.

Fig. I6. T.S. large vascular bundle of stem: ph. scler., phloem sclerenchyma; s.t., sieve-tube; g.t., ground tissue. $\times 620$.

\section{PLATE VIII.}

\section{Earina mucronata (continued).}

Fig. I 7. L.S. stem, ground tissue and tracheides: tr., tracheides; g.t., ground tissue. $\times 620$.

Fig. I8. Branch and sheath, T.S. : scler., sclerenchyma; can., canal; gen.tis., general tissue; cor., cortex. Diagrammatic.

Fig. 19. Leaf sheath, T. S. : cut., cuticle; epi., epidermis; can., canal. $\times 360$.

Fig. 20. Branch, outer portion, T.S. : cor., cortex; grd.tis., ground tissue; st., starch. $\times 360$.

Fig. 2I. T. S.: two fibres from sclerenchyma cylinder of branch. $\times 620$.

Fig. 22. T. S. : leaf, about half-way between edge and midrib; assim.tis., assimilatory tissue; r.c., raphides cell. $\times 360$.

Fig. 23. T. S. : cell from lower portion of assimilatory portion of leaf, showing extensions at junction of two cells. $\times 620$.

Fig. 24. Leaf, T. S. : assim.tis., assimilatory tissue ; m.r., midrib; r.c., cell containing raphides. Diagrammatic. 
Fig. 25. T. S. stoma of leaf. $\times 360$.

Fig. 26. T.S. leaf edge: r.c., raphides cell ; inter.sp., intercellular space; scler., sclerenchyma group. $\times 360$.

Fig. 27 . T. S. midrib of leaf: w.t., cells bearing a slight resemblance to water tissue. $\times 360$.

\section{Earina suaveolens.}

Fig. 28. Root, T.S. outer portion : $v$., velamen ; p.c., passage cell ; exo., exodermis; r., raphides ; fung., fungus; $\mathrm{k}$, one of the usual two small cells adjoining a passage cell; t.c., cross-wall of a reticulately pitted cell. $\times 360$.

Fig. 29. T. S. reticulately pitted cell from inner portion of cortex of root. $\times 6$ a.

Fig. 30. L. S. spirally marked cells, middle of cortex, root: sp.b., spiral band. $\quad \times$ II 2.

Fig. 31. Raphides cell, L. S., root. $\times 360$.

Fig. 32. T. S. cortical cell adjoining endodermis, root. $\times 620$.

Fig. 33 L. S. cortical cell adjoining endodermis, root. $\times 360$.

Figs. 34, 35. Usual forms of tracheides, root. $\times 620$.

Fig. 36. T. S. central cylinder, root : end., endodermis ; p.c., passage cell ; cell.peri., cellulosewalled element of pericycle adjoining a passage cell ; cut.w., cells with cutinized walls. $\times 360$.

\section{PLATE IX.}

\section{Earina suaveolens (continued).}

Fig. 37. Stem, outer portion, T. S.: epi., epidermis; f.v.b.sh., sheath of a vascular bundle. $\times$ II 2.

Fig. 38. T. S.: one of larger vascular bundles of stem: st., starch; gr.tis., ground tissue. $\times 360$. $\times 360$.

Fig. 39. Leaf sheath, T.S. : can., canal ; r.m., reticulately pitted cells of the general tissue.

Fig. 40. Leaf sheath, L. S. : to show increase in number and size of pits from epidermis inwards. $\times 360$.

Fig. 4I. Leaf, T.S.: m.r., midrib ; assim.tis., assimilatory tissue. Diagrammatic.

Fig. 42. Leaf, midrib, T. S. : w.st., water-storage cells. $\times 360$.

Fig. 43. T. S. cells from lower portion of assimilatory region of leaf: to show linking of the cells; no chlorophyll indicated. $\times 620$.

Fig. 44. Leaf, T.S., half-way towards edge : pal., palisade-like layer; r.c., ring of somewhat regular assimilatory cells surrounding the vascular bundle. $\times 360$.

\section{Dendrobium Cunninghamii.}

Fig. 45. Root, T.S., central cylinder : end., endodermis; p.c., passage cell ; peri., pericycle; cut.tis., cutinized tissue; ph.f., phloem fibre; com.c., companion cell. $\times 620$.

Fig. 46. L. S. cortex, root. $\times$ I I2.

Fig. 47. Root, outer portion, T. S. : rt.h., root-hair; fung., fungus; rad.m., radial strands; pyr.c., pyramidal cells over passage cell ; b.st., section of thickening strand. $\times 360$.

Fig. 48. L. S. endodermis, root: i.c., cell of cortex; p.c., slightly elongated passage cell ; cell.p., cellulose-walled pericyclic element; ord.peri., cutinized pericyclic element. $\times 620$.

Fig. 49. Root, T. S., centre of cylinder: cut.tis., cutinized tissue; cell.w., central cell with cellulose walls. $\times 620$.

Fig. 5o. Stem, T. S. : sil., peripheral cylinder of sclerenchyma; cor., cortex ; gr.tis., ground tissue. Diagrammatic.

Fig. 5r. T. S. cortical cell of stem : int.sp., intercellular space. $\times 620$.

\section{PLATE X.}

\section{Dendrobium Cunninghamii (continued).}

Fig. 52. Leaf, T.S. : m.r., midrib; r.c., raphides.cell. Diagrammatic.

Fig. 53. Leaf, T. S., portion between two vascular strands; t.c., cylinder of small hexagonal cells immediately surrounding a vascular strand; l.cut., cuticle of lower surface. $\times 360$.

Fig. 54. T. S. vascular bundle of leaf. $\times 620$. 
Fig. 55. T. S. tissue over midrib of leaf : contents much vacuolated. $\times 620$.

Fig. 56. T. S. upper epidermis of leaf : cl.c., club-shaped cell ; b.c., basal cell ; $p$., small round pits common throughout epidermis; $\not p$., elongated pit ; $c$., compact tissue in neighbourhood of basal cell. $\times 620$.

\section{Bulbophyllum pygmaeum.}

Fig. 57. Root, T. S. : p.c., passage cell; $v$., velamen; exo., exodermis ; r.w., radial wall of velamen tapering in thickness towards the free surface. $\times 360$.

Fig. 58. Stem, T. S. : o.c., outer portion of cortex; i.c., inner portion of cortex ; f.v.b., vascular bundle. Diagrammatic.

Fig. 59. Stem, T.S., outer portion : e., epidermis ; o.c., outer portion of cortex ; t.c., reticulately pitted cell; i.c., inner portion of cortex. $\times 360$.

Fig. 6o. Vascular bundle of stem, T.S.: gr.tis., ground tissue. $\quad \times 620$.

Fig. 6I. Pseudo-bulb, L. S. : cav., cavity at apex; tis., general tissue; ps.b., pseudo-bulb; f.v.b.s., vascular strands of stem; f.v.b.rt., vascular strands of root. Diagrammatic.

Fig. 62. Surface view, epidermal cell of pseudo-bulb. $\times 360$.

Fig. 63. Surface view, spiral cell of psendo-bulb. $\times$ I 2 .

Fig. 64. Pseudo-bulb, T.S. through apical region : ps.b., pseudo-bulb; cut., cuticle of surface of psendo-bulb cavity and of lower surface of leaf; u.s., upper surface of leaf; l.s., lower surface of leaf; scl., sclerenchyma; ph., phloem. Diagrammatic.

Fig. 65. T. S. vascular bundle of pseudo-bulb; t.c, tracheide-like cell. $\times 360$.

Fig. 66. General tissue of pseudo-bulb, L. S. : sp., water-storage cell. $\times 360$.

Fig. 67. Leaf, T.S. : p.t., region of palisade arrangement; epi., epidermis. Diagrammatic.

\section{PLATE XI.}

\section{Bulbophyllum pygmaeum (continued).}

Fig. 68. Leaf, T.S.: pap., papilla; pr., protoplasm; pal.tis., palisade arrangement of cells; on the lower right-hand side three cells are figured without chlorophyll to show connexions. $\times 360$.

\section{Bulbophyllum tuberculatum.}

Fig. 69. Stem, outer portion, T.S. : l.c., large vacuolated cell ; rh.c., raphides cell; par.tis., parenchymatous tissue. $\times$ II2.

Fig. 70. T.S. vascular bundle of stem. $\times 620$.

Fig. 7 I. L. S. raphides cell of leaf.

Fig. 7 2. T.S. onter portion of root: $f . w$. , thin outer wall of velamen; $t . w$. , thick radial wall; c., cortical cell. $\times 360$.

Fig. 73. Root, central cylinder, T.S.: p.c., two passage cells together; cell.peri., cellulose element of pericycle. $\times 620$.

Fig. 74. T. S. margin of leaf: e.c., projecting cell of leaf edge. $\times$ II 2.

Fig. 75. T. S. pseudo-bulb: m.c., water-storage cell. $\times 360$.

Fig. 76. Leaf, T.S. : m.r., midrib; u.epi., upper epidermis. Diagrammatic.

Fig. 77. T. S. lower portion of leaf : el.c., elongated cells between the vascular bundles; scler., part of sclerenchyma sheath; t.a., slight tubular connexion; pass., stomatal cavity. $\times 360$.

Fig. 78 . T. S. midrib of leaf : t.w., thickened wall of epidermis. $\times 360$.

Fig. 79. L. S. pseudo-bulb : m.c., water-storage cell; inter.sp., intercellular space. $\times$ II 2.

Fig. 8o. T. S. vascular bundle of pseudo-bulb: pr.e., protective element. $\times 360$.

Fig. 8I. L. S. psendo-bulb, near apex : pur.c., cell containing purple, sap; m.c., water-storage cell. $\times$ II 2 .

\section{Sarcochilus adversus.}

Fig. 82. Stem, outer portion, T. S. : p.c., parenchyma cell ; r.c., raphides cell. $\times$ II 2.

Fig. 83. T.S. cells of central ground tissue of stem, to show pits. $\times 360$.

Fig. 84. Stem, T.S. : gr.tis., ground tissue. Diagrammatic. 


\section{Species of the Nere Zealand Orchidaceae.}

\section{PLATE XII.}

Sarcochilus adversus (continued).

Fig. 85. T.S. vascular bundle of stem : com.c., companion cell; cut.w., cutinized cells. $\times 360$. Fig. 86. Leaf, upper portion, T.S.: $r$., raphides. $\times$ II 2.

Fig. 87. Leaf, T.S. Diagrammatic.

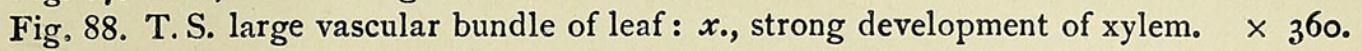

Fig. 89. T.S. outer portion of root: $m$., radial strands present in walls of outermost cells only; $l c . c$., somewhat large cortical cell adjoining a passage cell ; sp.c., spirally thickened cell ; $r$., raphides. $\times 620$. cell. $\times 360$.

Fig. 90. T.S. central cylinder, root: cell.peri., cellulose element of pericycle; cut.c., cutinized 
Annals of Botany,
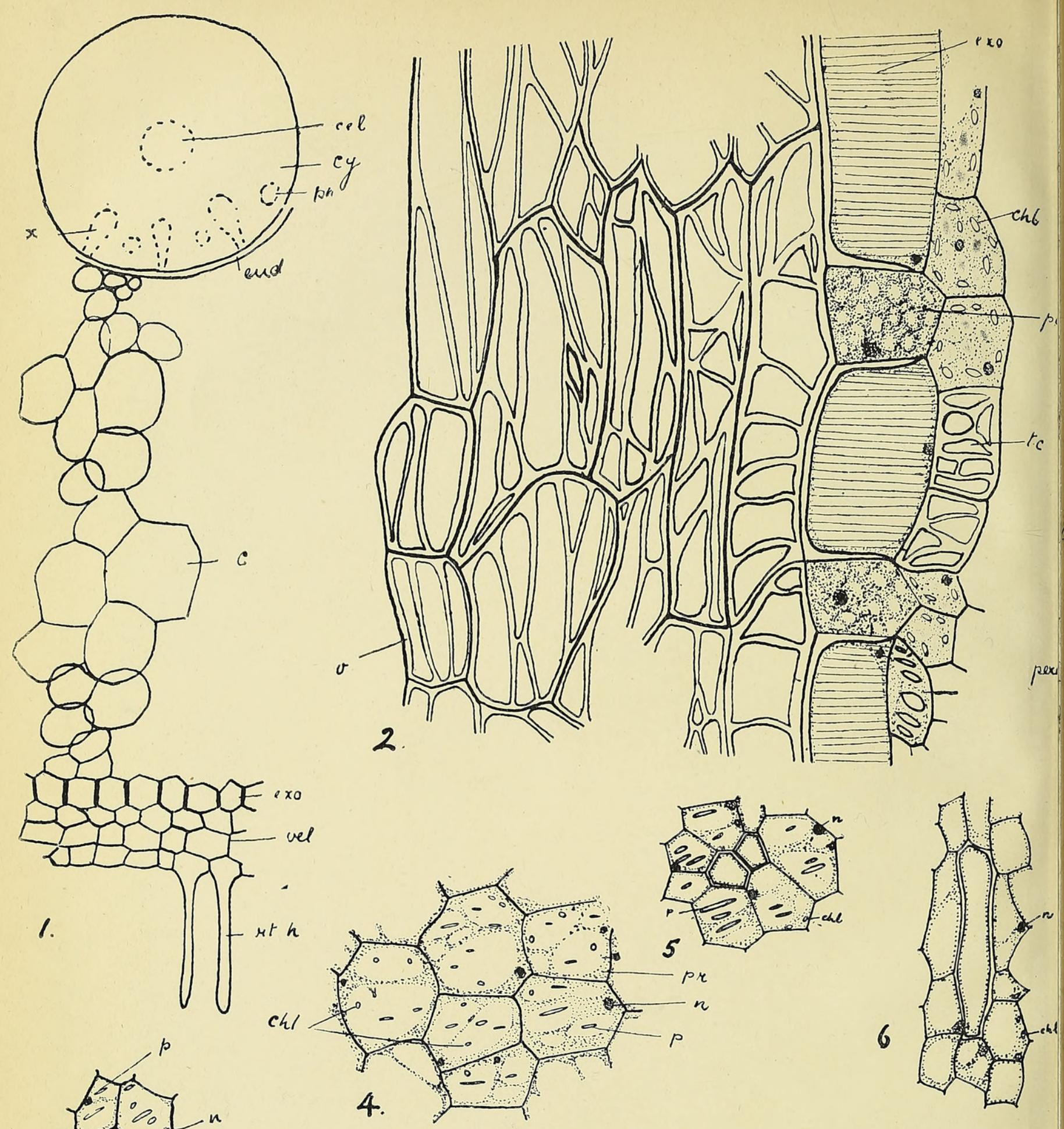

- Fon.

3. 21

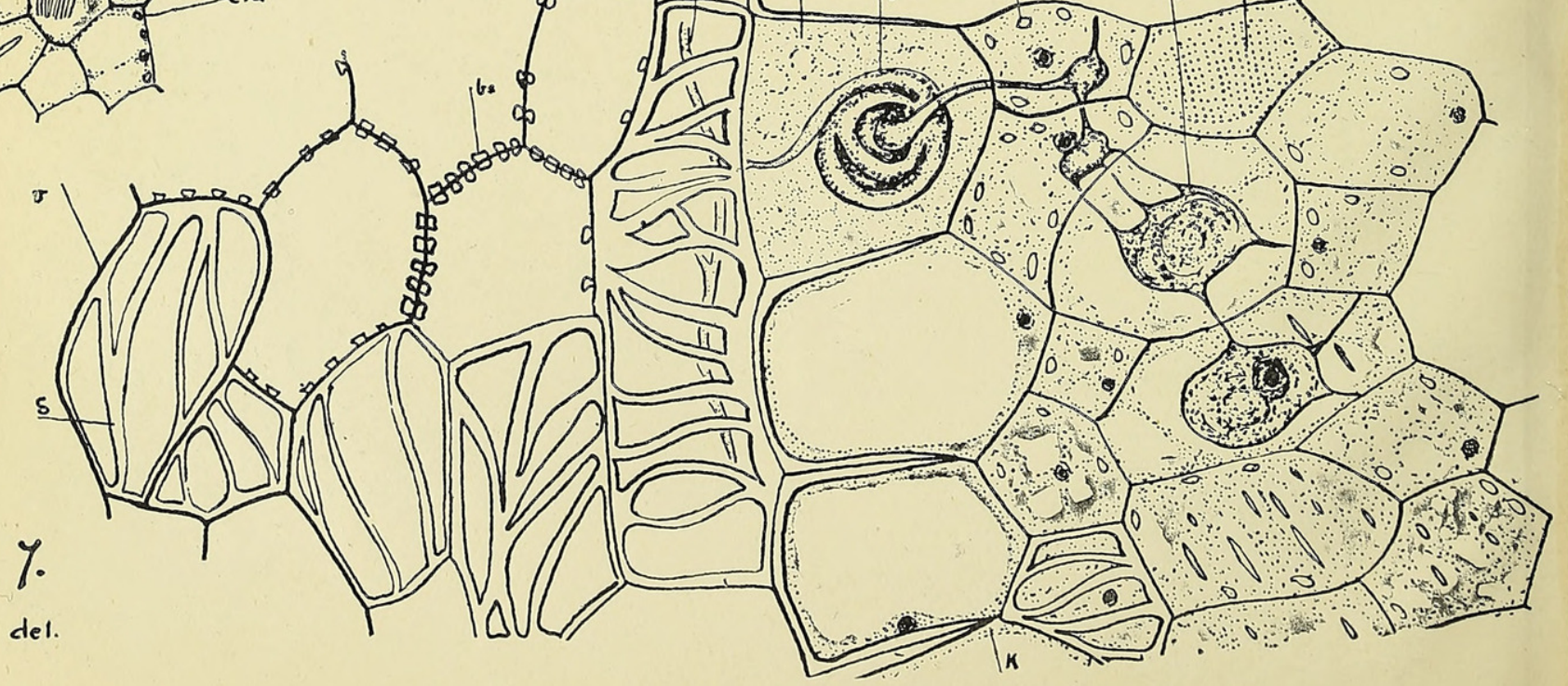

CURTIS-NEW ZEALAND ORCHIDS. 
Vol. XXXI, Pl. VII.
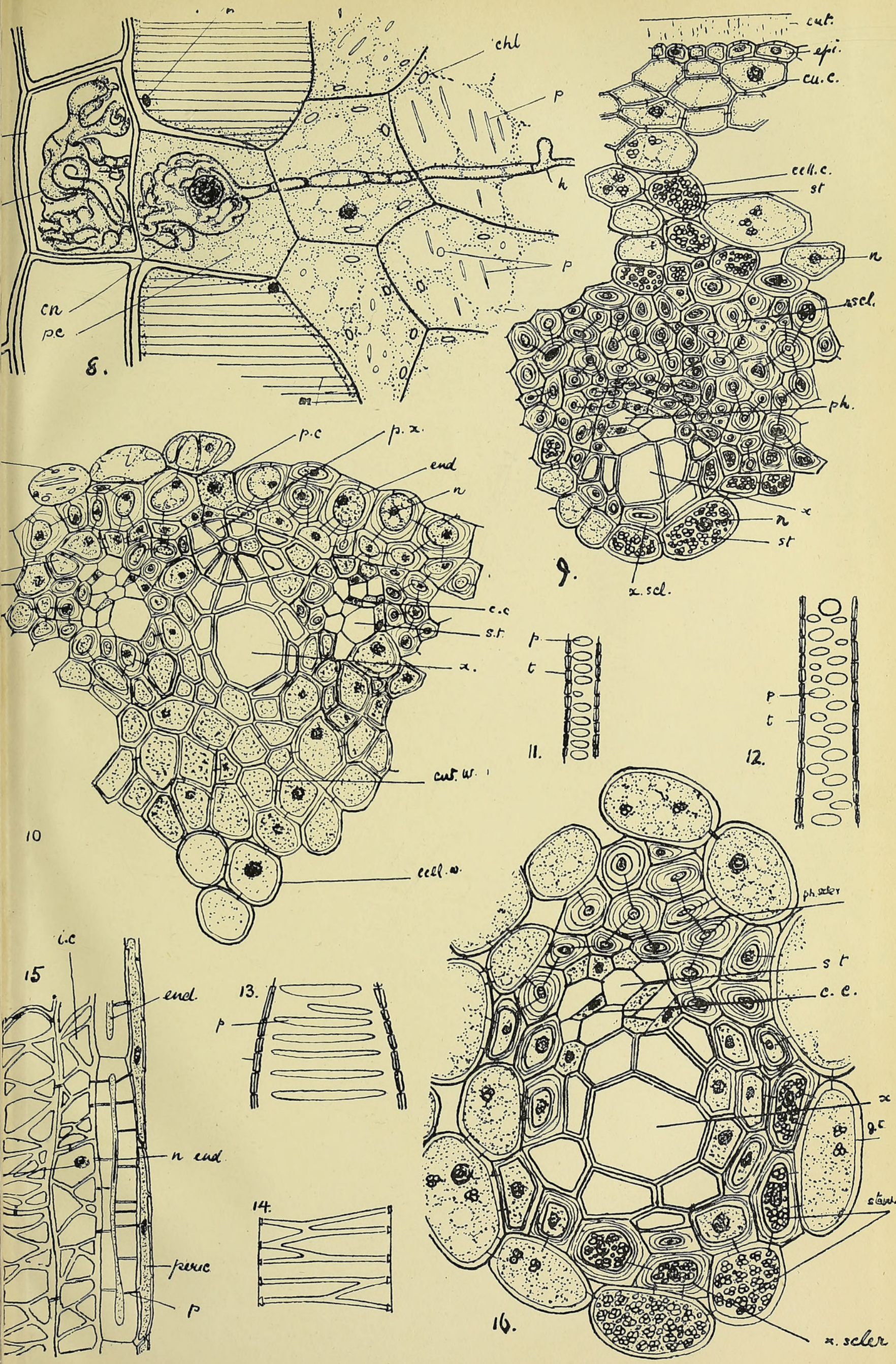
Annals of Botany,

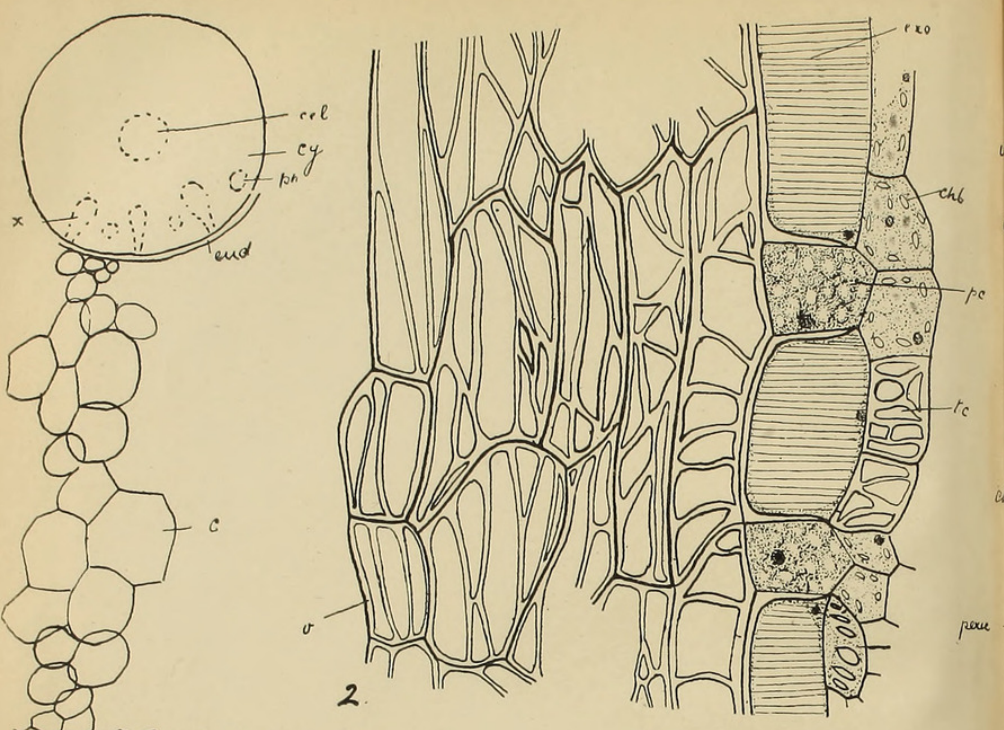

HODO0OE:

\section{र्गु ve}<smiles>C#CC1(C)C(C)C(C)(C)C1(C)C</smiles>

$$
\text { for. }
$$$$
\text { riot }{ }^{n} \text { 4. }
$$$$
\sum_{p}
$$

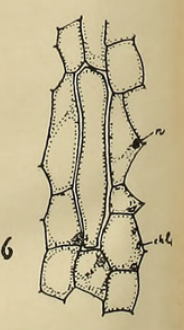

3.

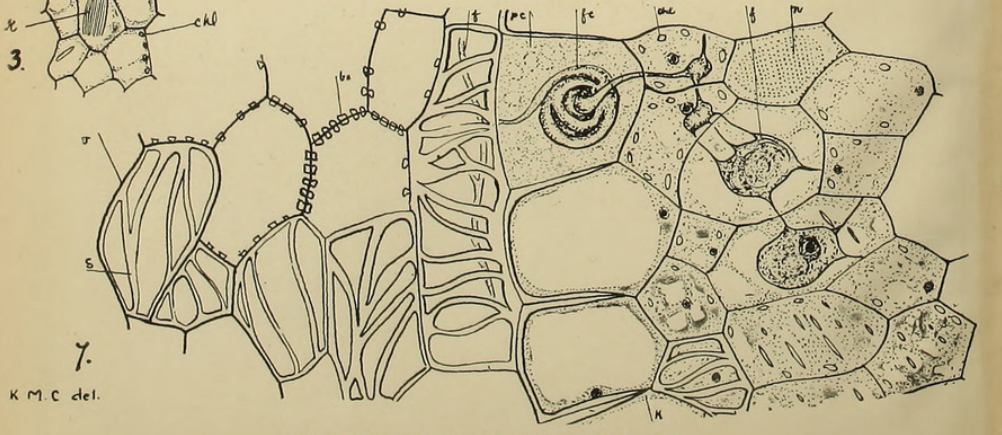

CURTIS-NEW ZEALAND ORCHIDS.

Vol. XXXI, Pl. VII.

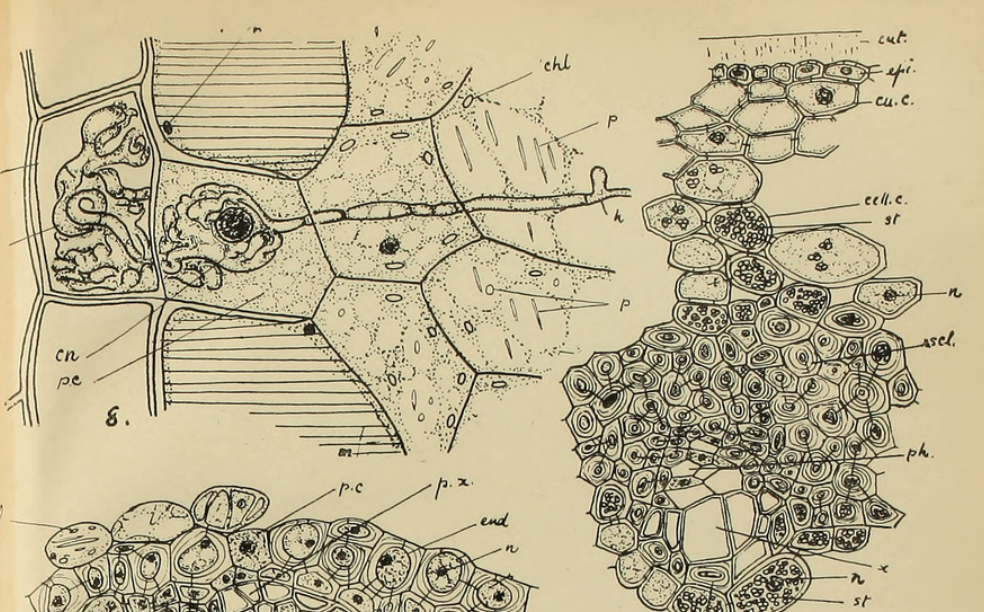

(3)

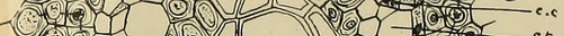
(a) 010.0

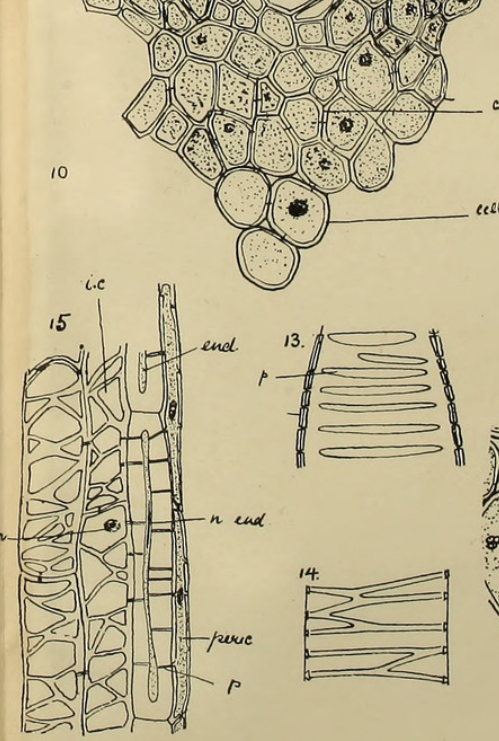

16.

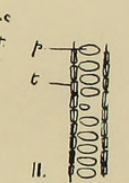

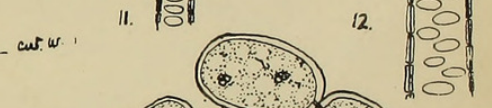
o요

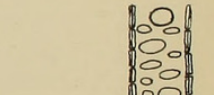

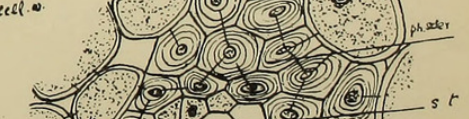

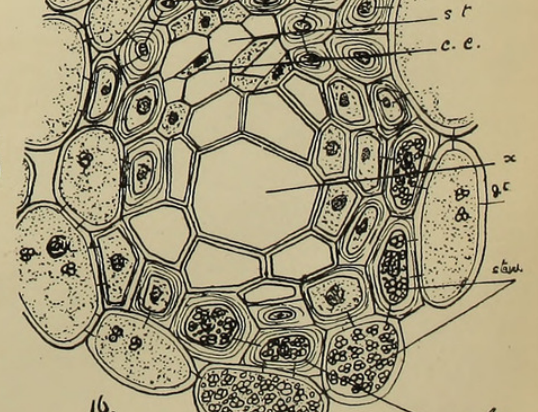


Annals of Botany,
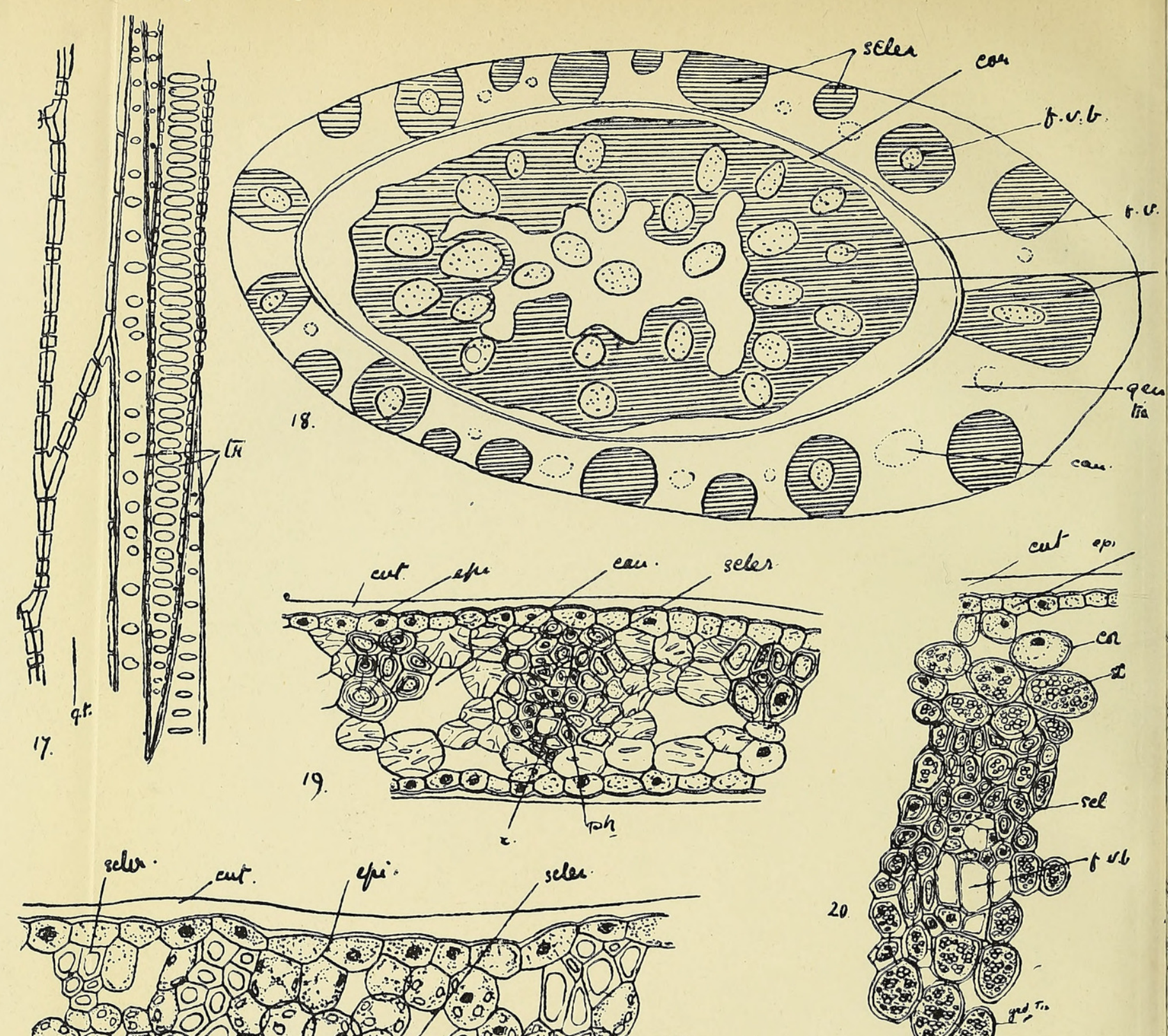

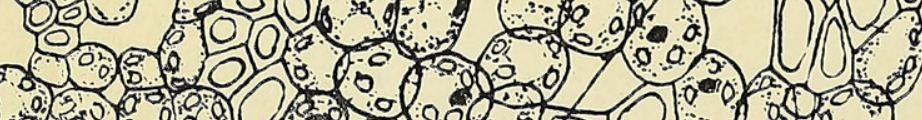

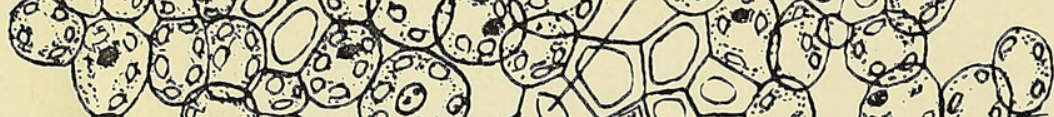

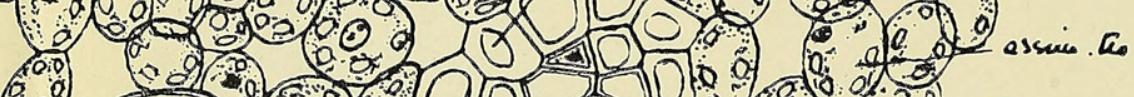

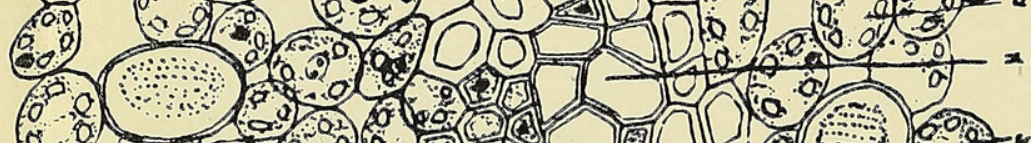

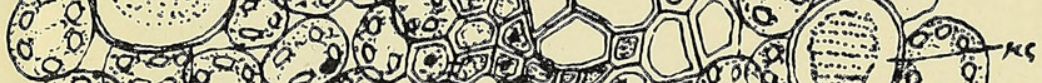

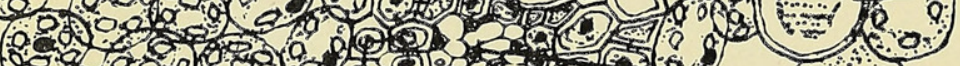

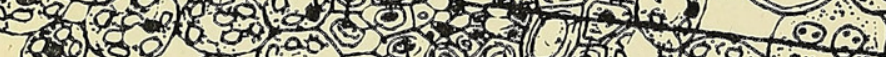

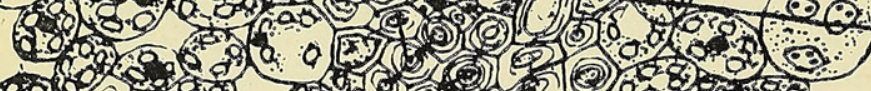
o ( )

22. 100100100

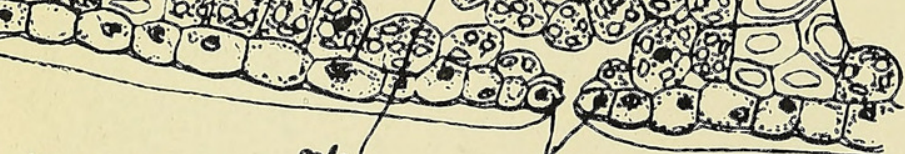

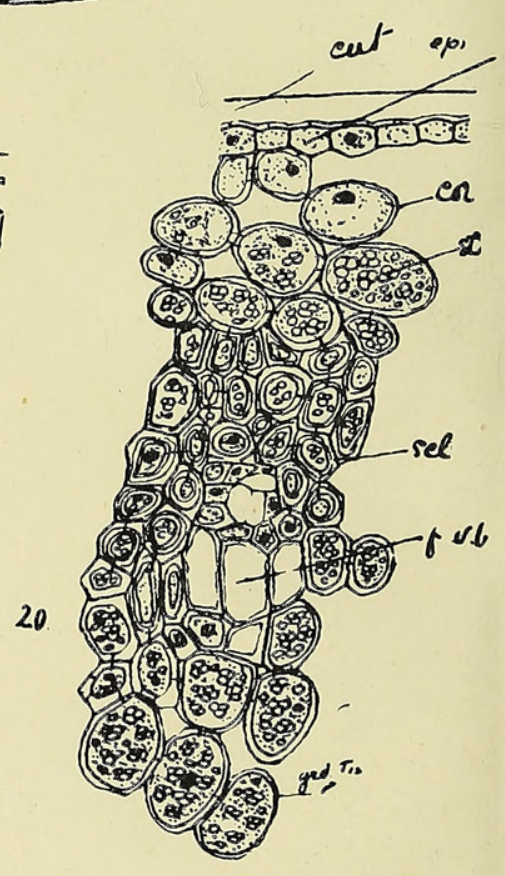

K.M. C. cleI. seler. seles. seles. siona 


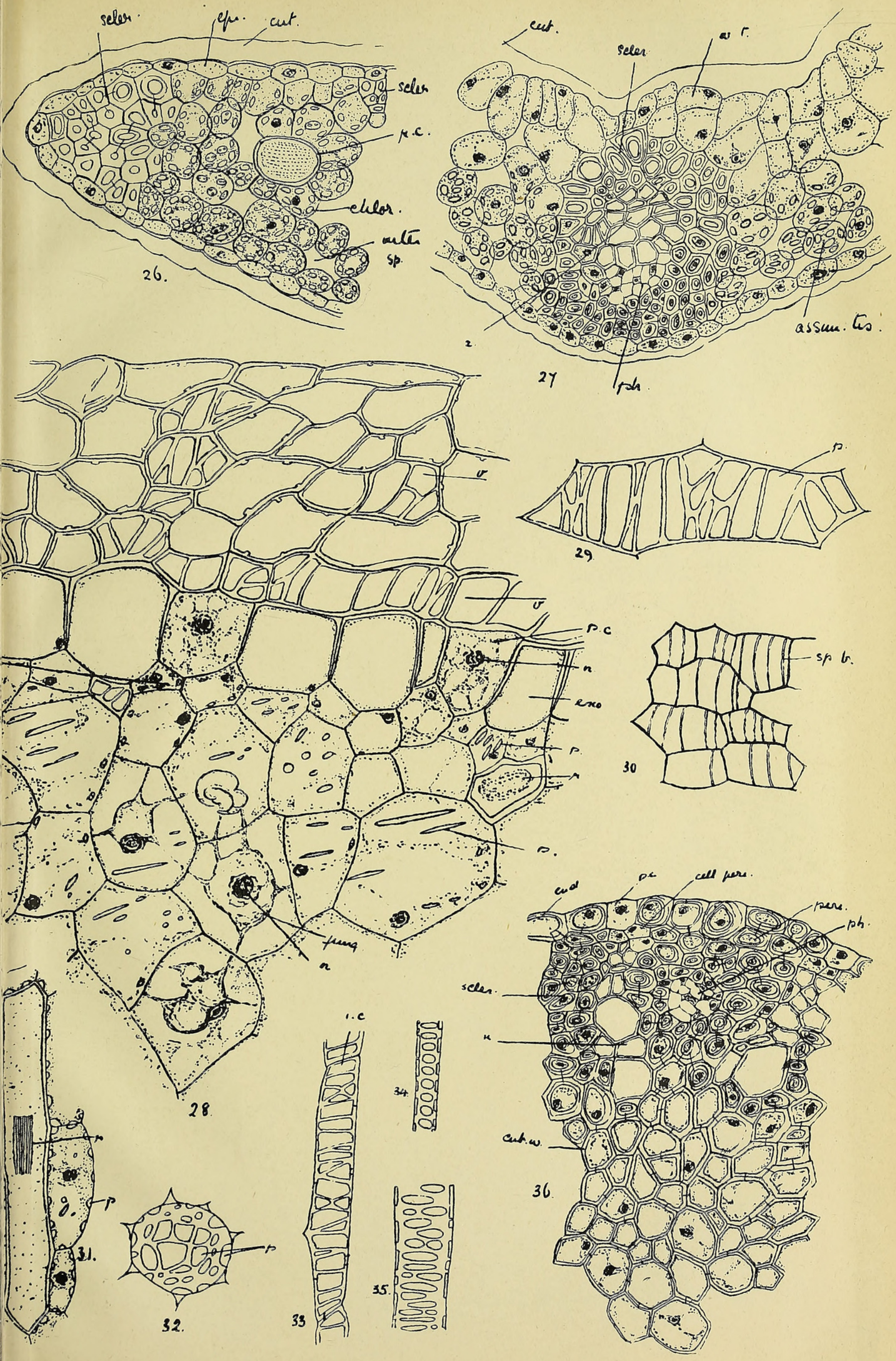


Annals of Botany,

Vol. XXXI, Pl. VIII.
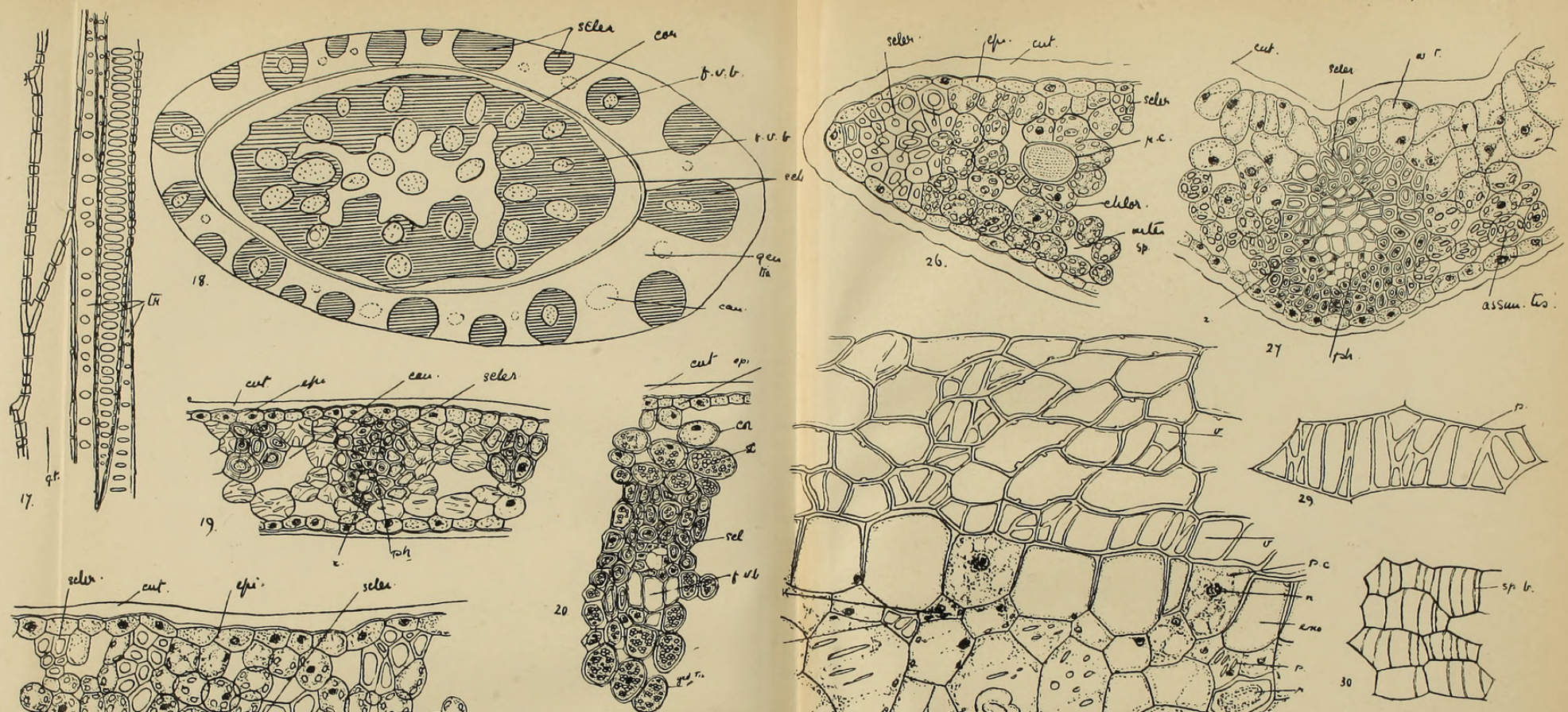

(7.0.)

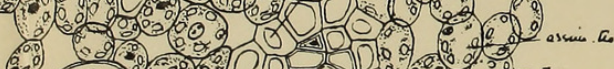

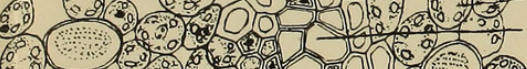

(6)
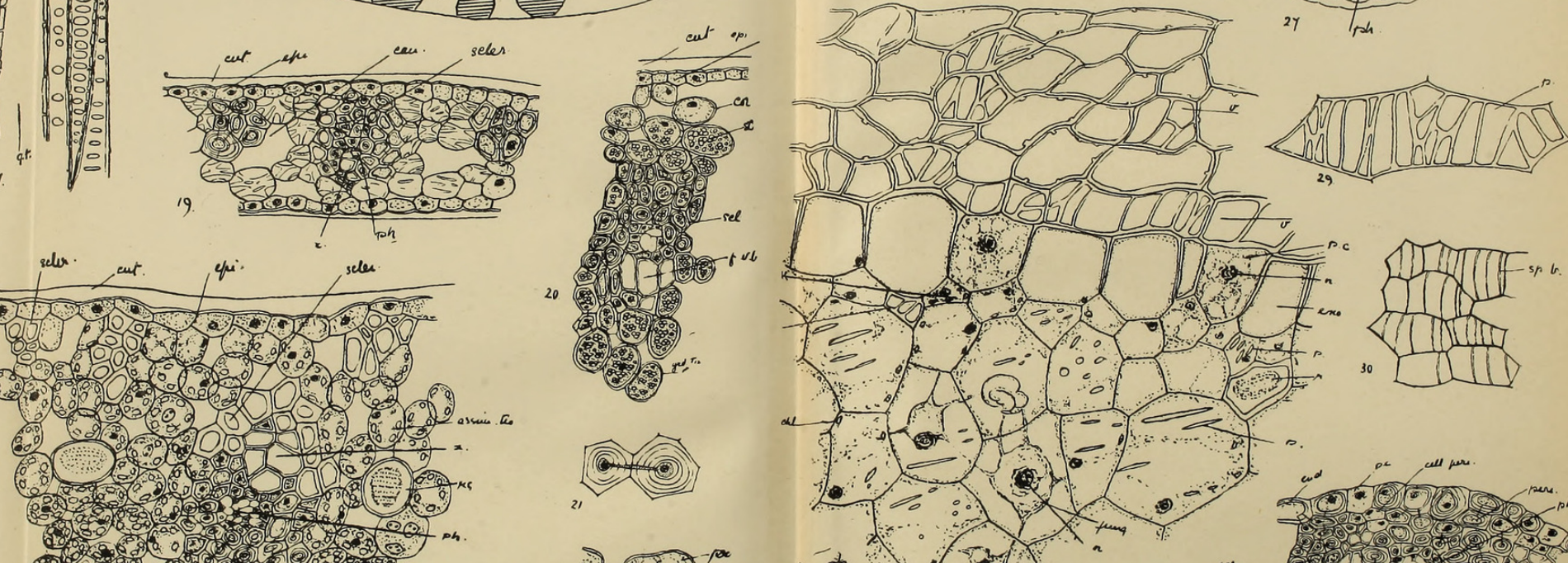

22.

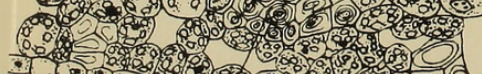

1.....
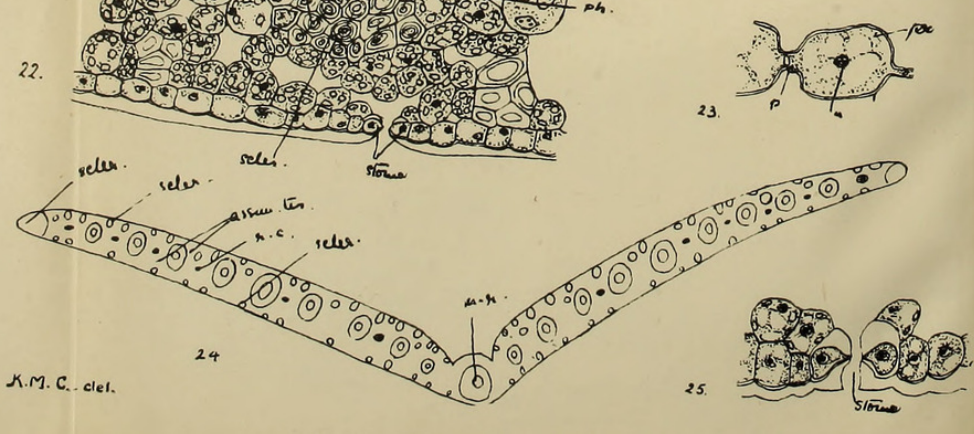

CURTIS-NEW ZEALAND ORCHIDS.

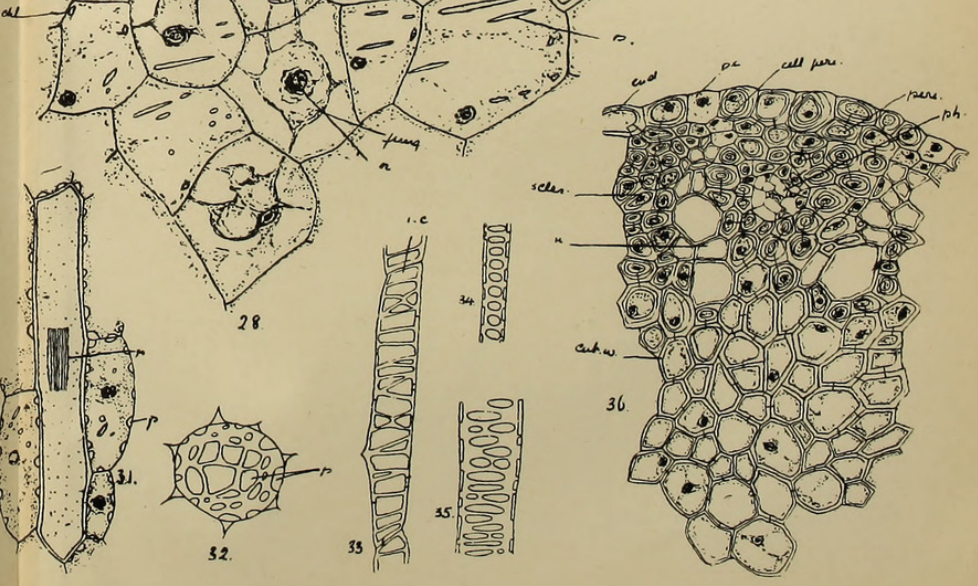


Annals of Botany,

Vol. $X X X I, P l . I X$.

"
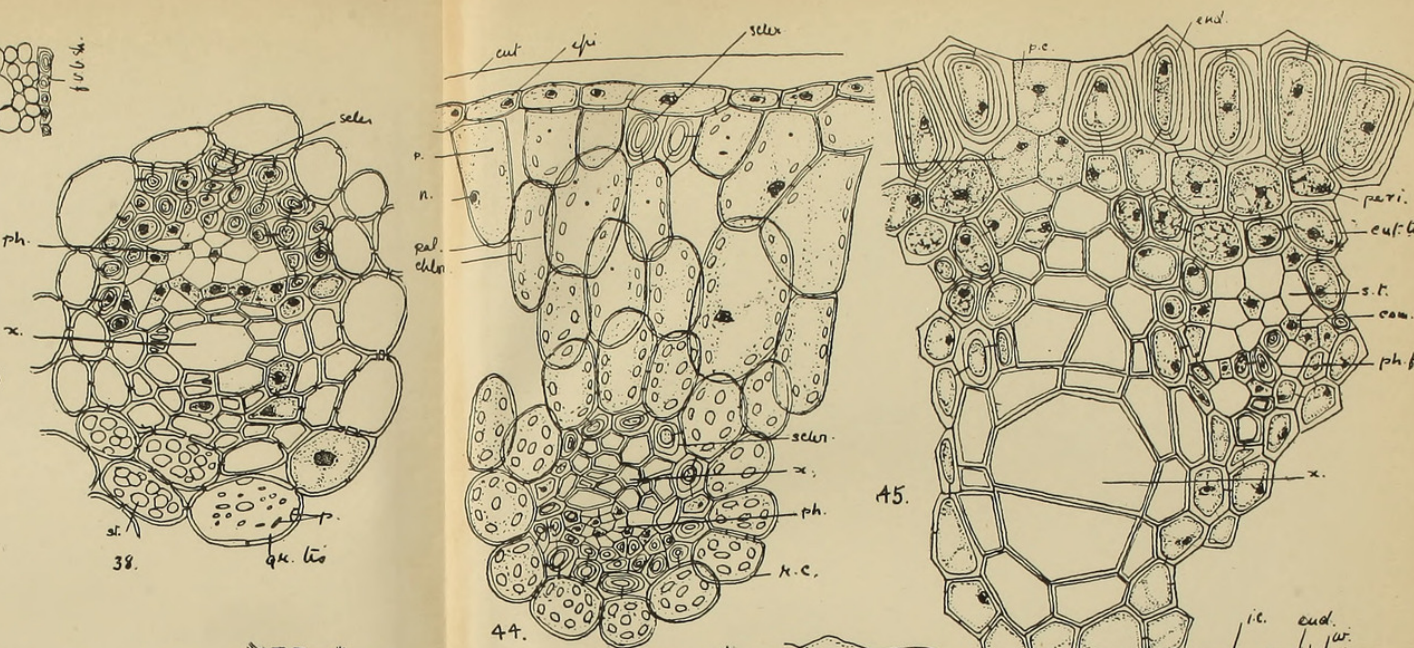

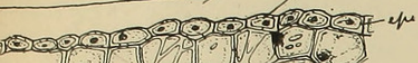

$-100.10$

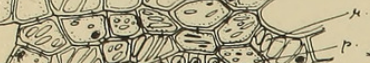

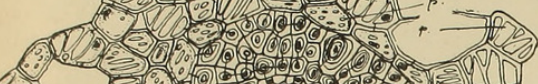

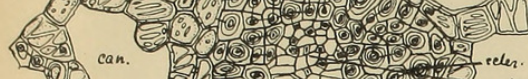
(2) 30 mon

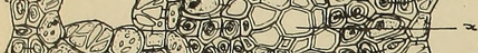

2.

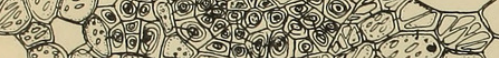

iें

39.

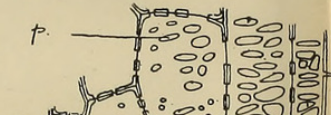
44. 0.09$)\left(\begin{array}{llll}0.0 & 0 \\ 0 & 0 & 0\end{array}\right.$

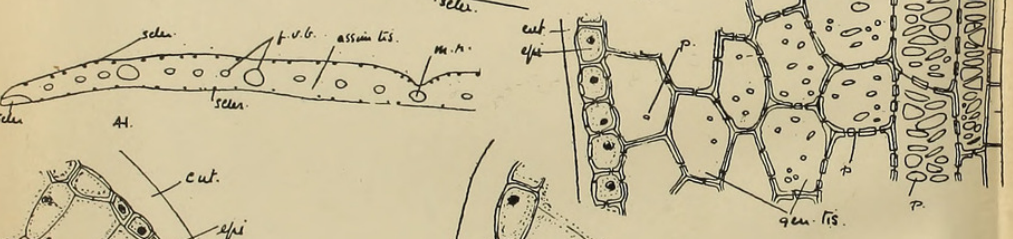

$$
\text { . }
$$
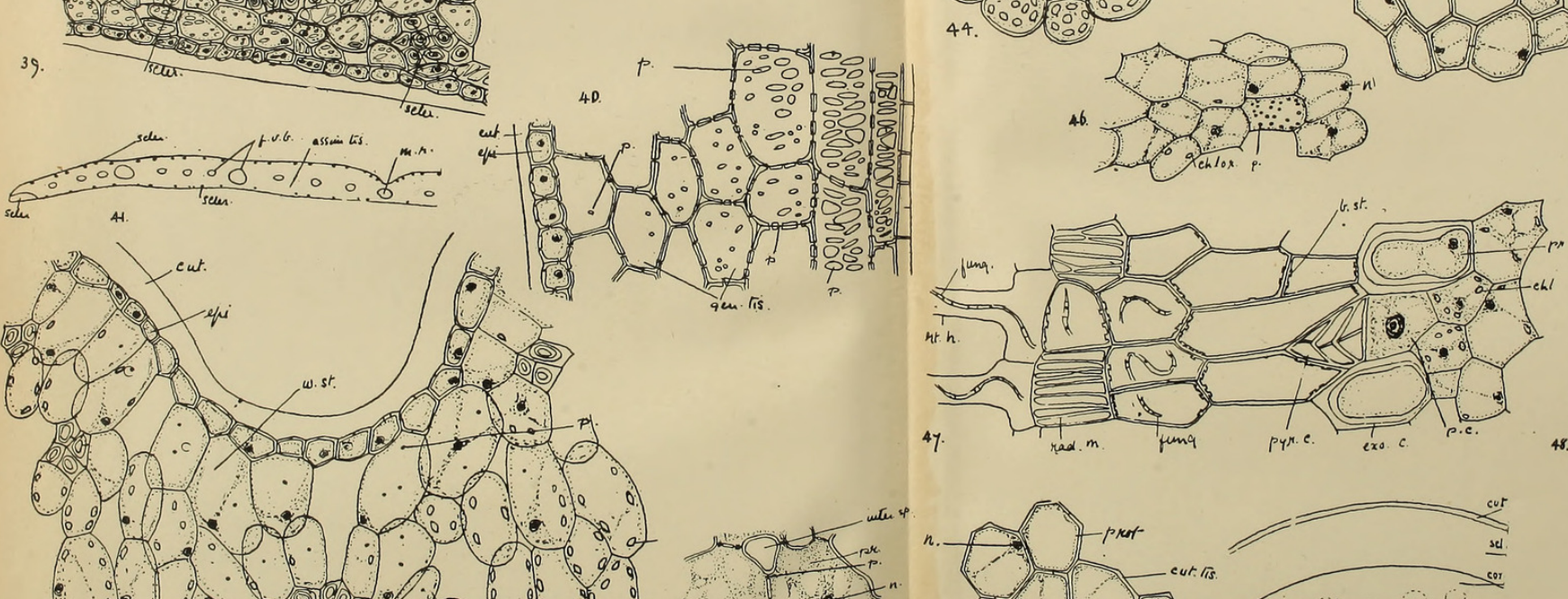

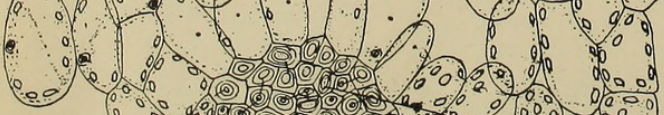

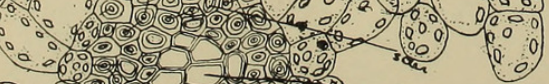

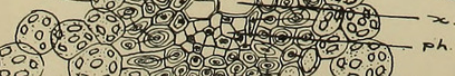

ग0 $10090 \%$

CURTIS-NEW ZEALAND ORCHIDS.
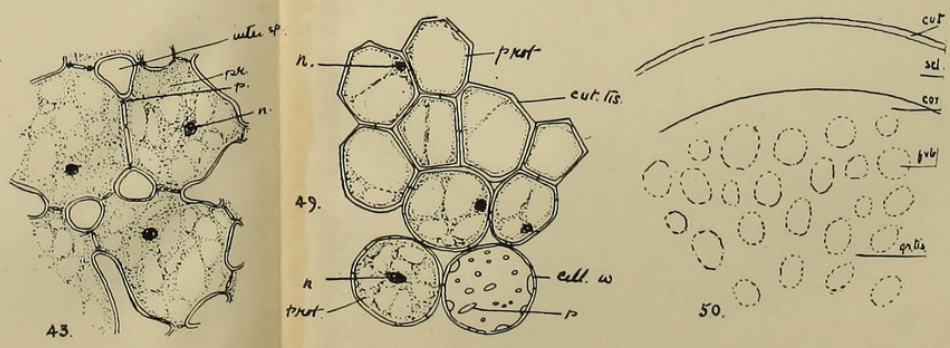

48.

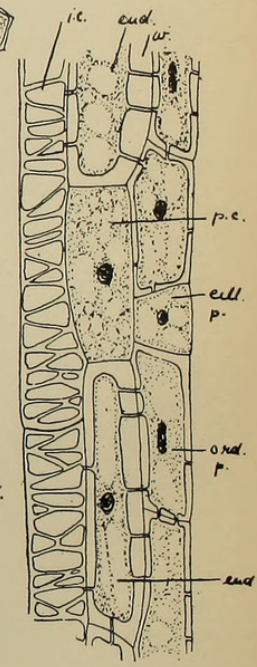


Annals of Botany,
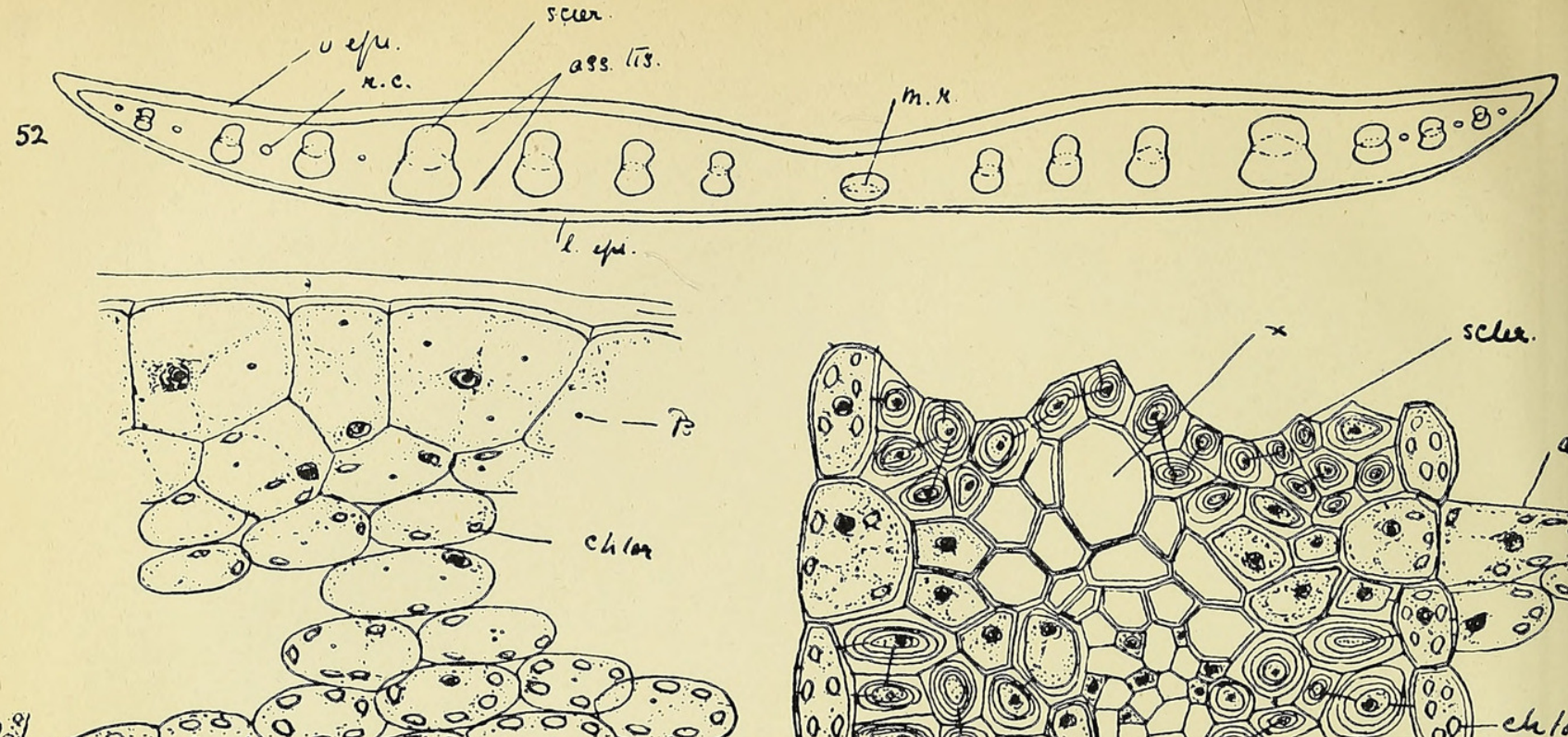

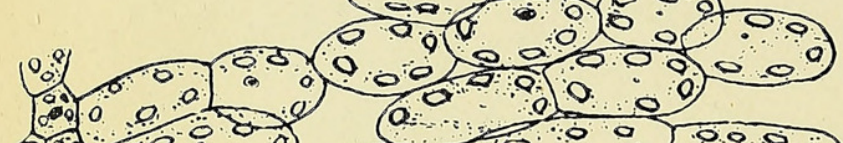

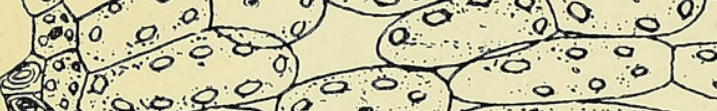

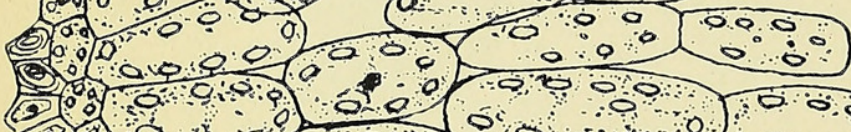

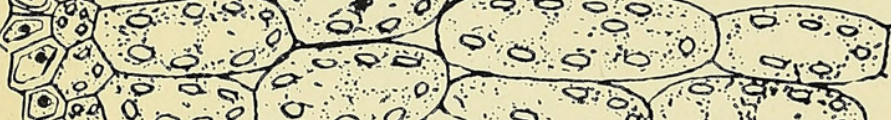

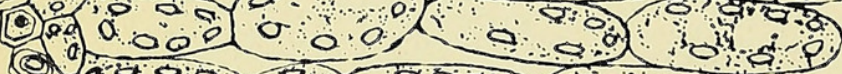

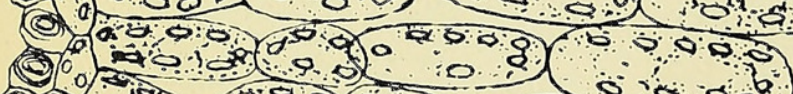

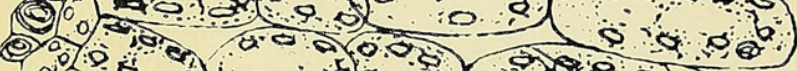

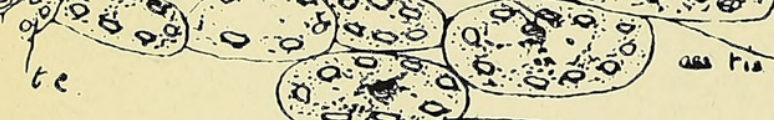

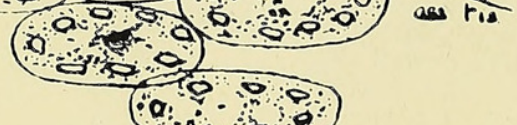

$$
\begin{aligned}
& \left(0 \begin{array}{c}
0 \\
0 \\
0
\end{array}\right.
\end{aligned}
$$
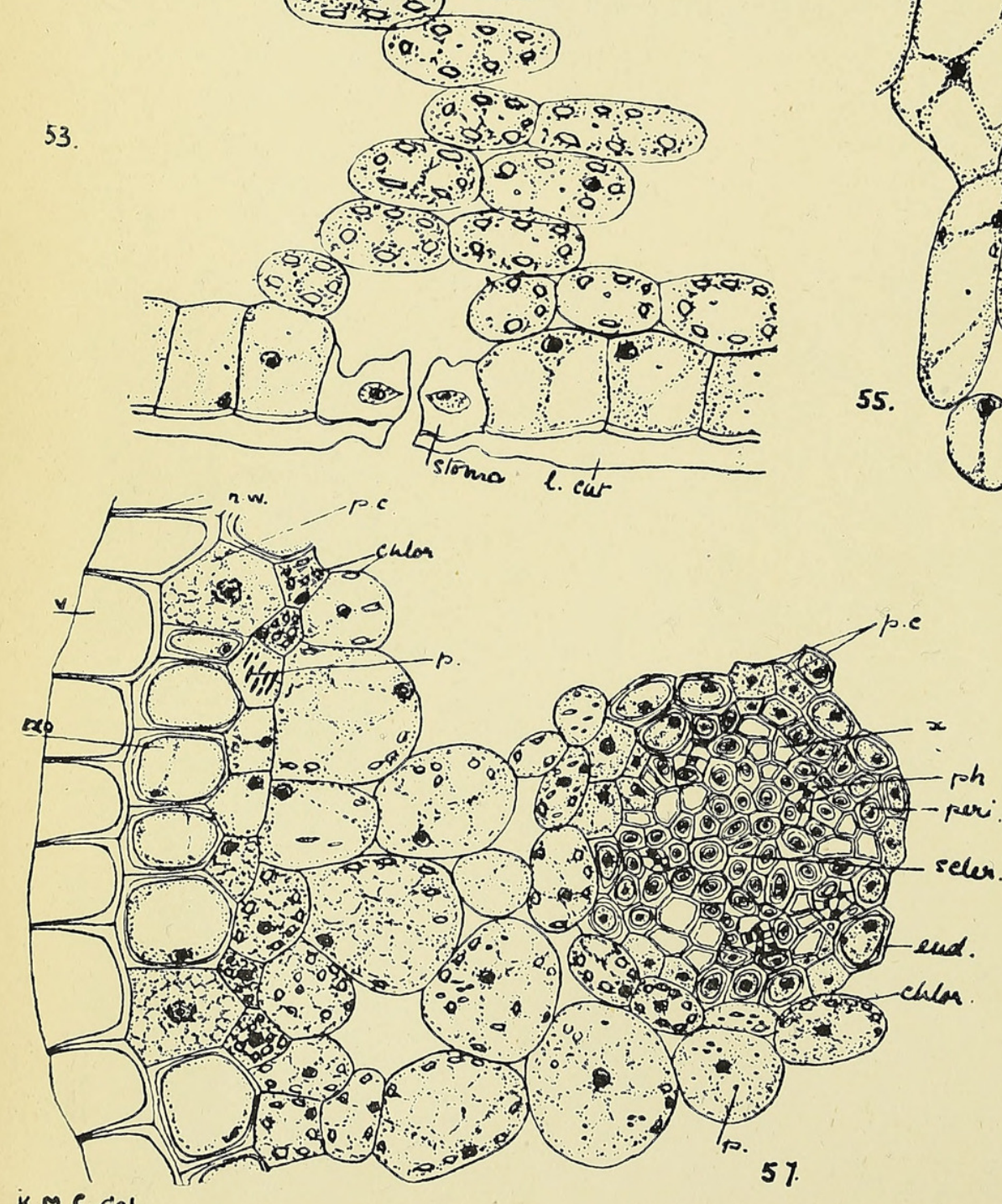

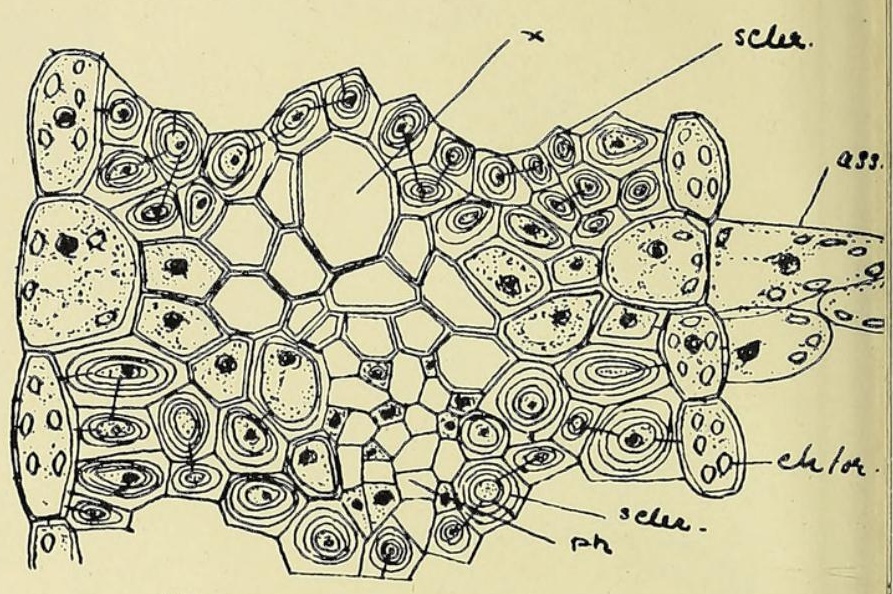

54

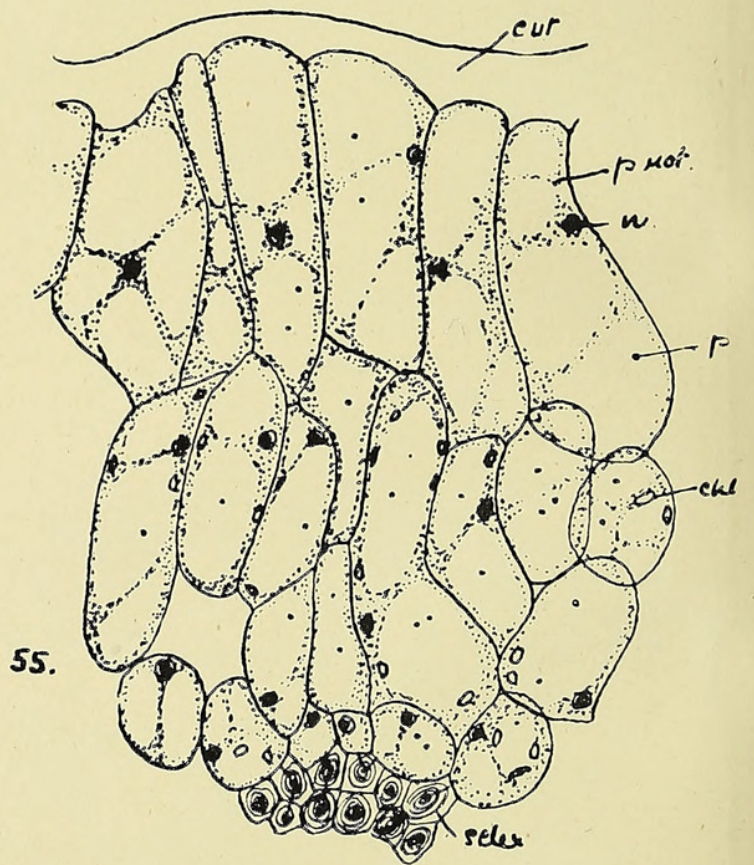


Vol. $X X X I, P l . X$.
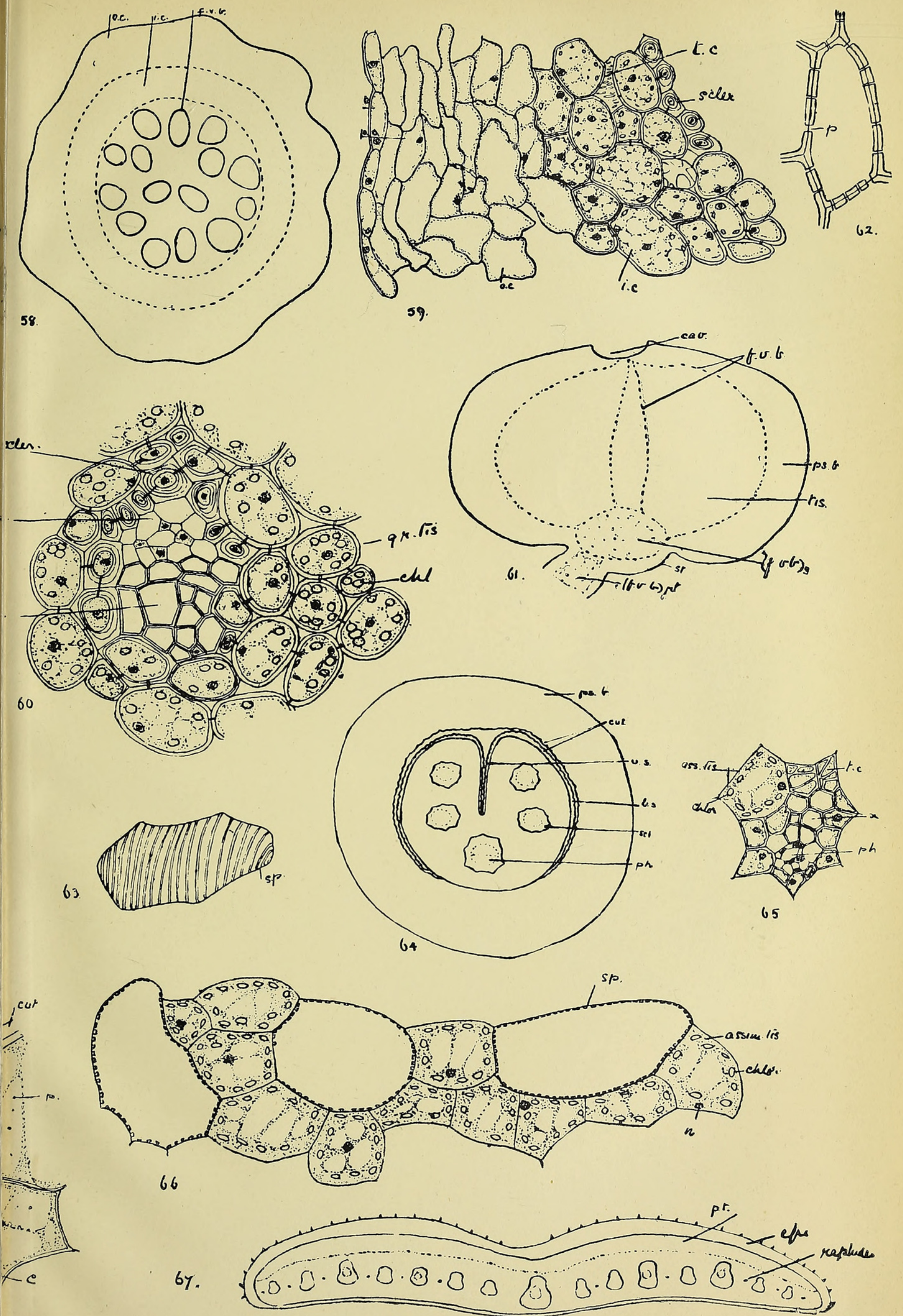
Annals of Botany,

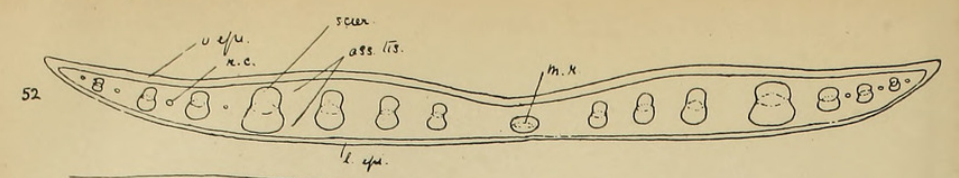

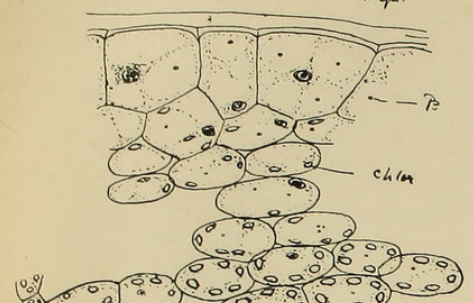

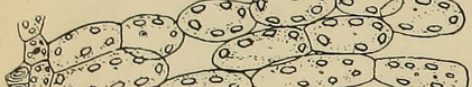

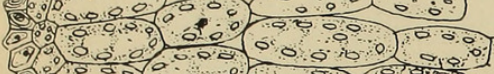

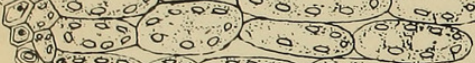

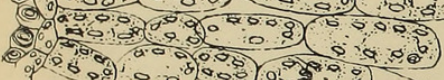

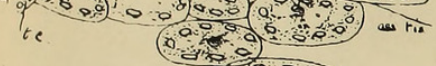
$\frac{(0.90)}{0.00}$

53.
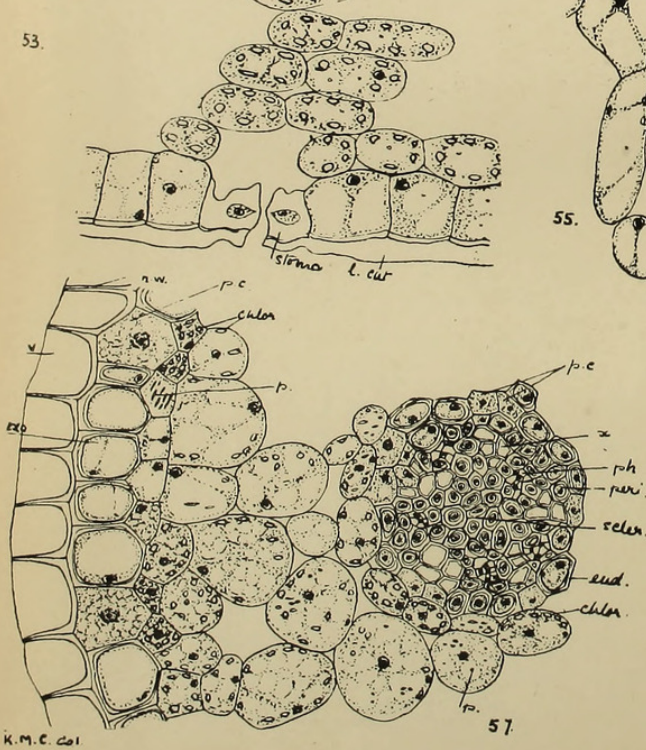

55.
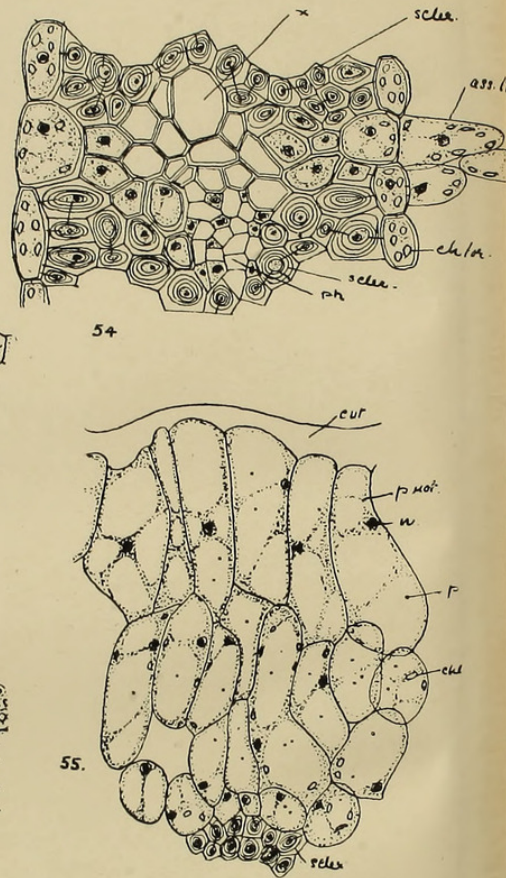

54

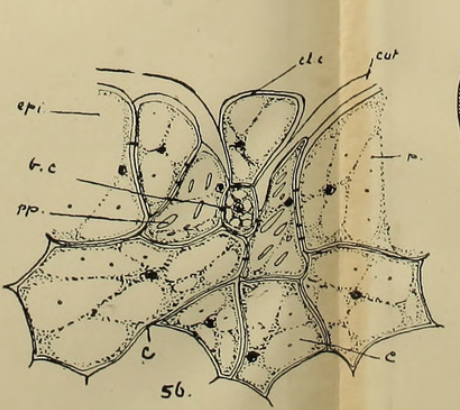

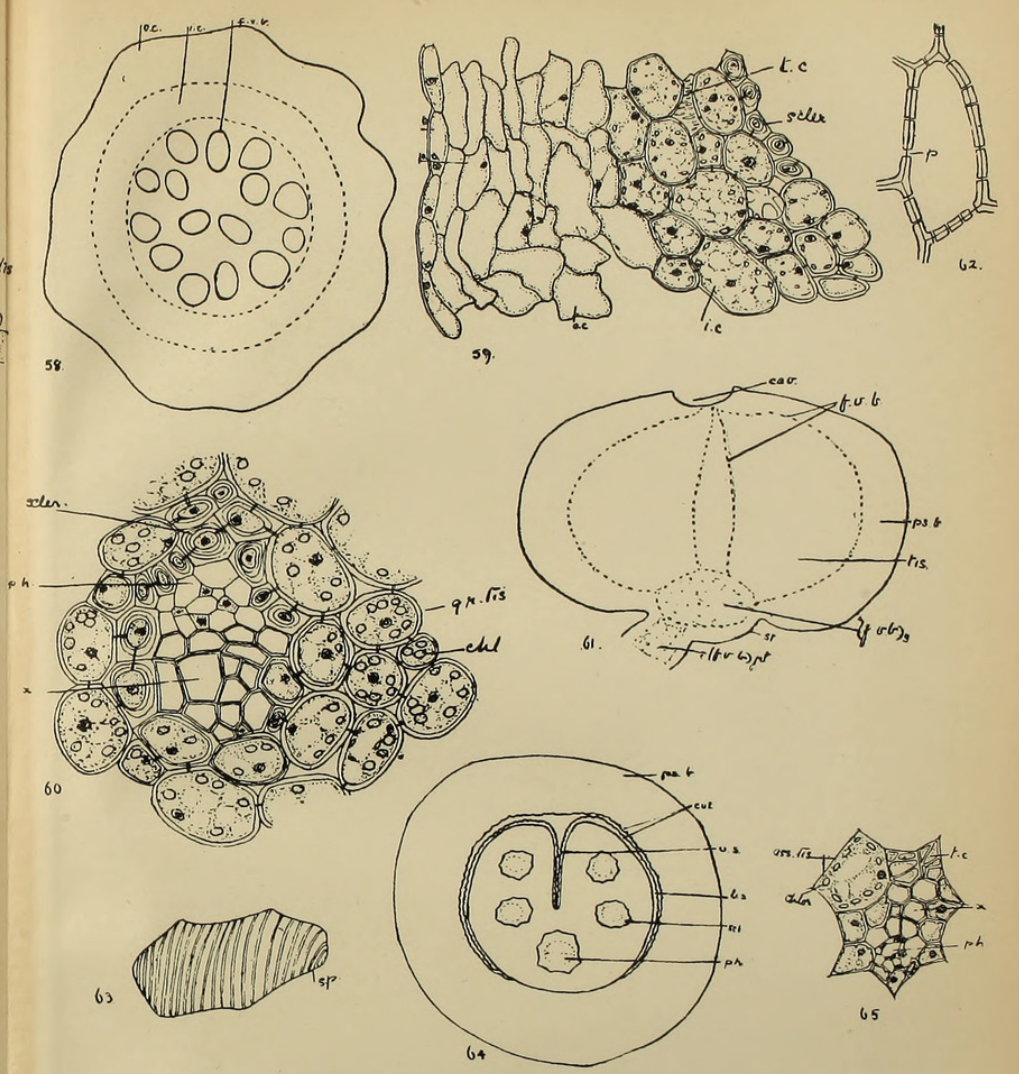

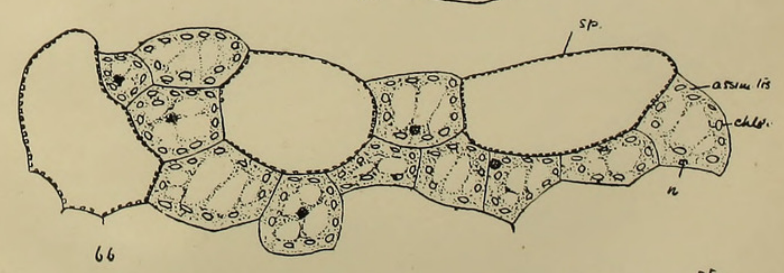

66

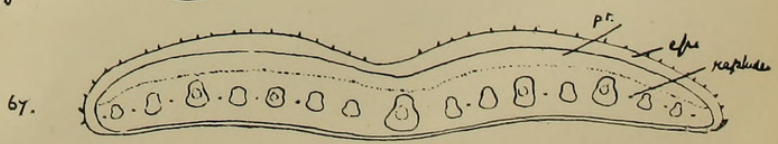


Annals of Botany,

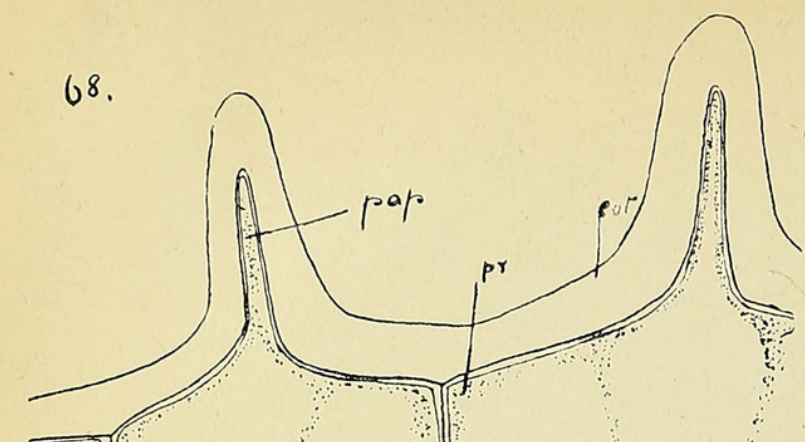




\section{$2 \mathrm{BHL}$ Biodiversity Heritage Library}

Curtis, K. M. 1917. "The anatomy of the six epiphytic species of the New Zealand Orchidaceae." Annals of botany 31, 133-149. https://doi.org/10.1093/oxfordjournals.aob.a089632.

View This Item Online: https://www.biodiversitylibrary.org/item/232813

DOI: https://doi.org/10.1093/oxfordjournals.aob.a089632

Permalink: https://www.biodiversitylibrary.org/partpdf/320179

\section{Holding Institution}

Smithsonian Libraries

\section{Sponsored by}

Biodiversity Heritage Library

\section{Copyright \& Reuse}

Copyright Status: Not in copyright. The BHL knows of no copyright restrictions on this item.

This document was created from content at the Biodiversity Heritage Library, the world's largest open access digital library for biodiversity literature and archives. Visit BHL at https://www.biodiversitylibrary.org. 